Elsevier required licence: (C) $<2020>$. This manuscript version is made available under the CC-BY-NCND 4.0 license http://creativecommons.org/licenses/by-nc-nd/4.0/

The definitive publisher version is available online at

[https://www.sciencedirect.com/science/article/pii/S0360131519302477?via\%3Dihub] 


\title{
How does students' general academic achievement moderate the implications of social networking on specific levels of learning performance?
}

\author{
James Wakefield ${ }^{\mathrm{a}}$ \& Jessica K. Frawley ${ }^{\mathrm{b}}$ \\ ${ }^{a}$ UTS Business School, University of Technology Sydney, Australia \\ ${ }^{\mathrm{b}}$ Sydney School of Architecture, Design and Planning, University of Sydney, Australia
}

*Corresponding author, James Wakefield

UTS Business School, Accounting, University of Technology Sydney

City Campus, PO Box 123 Broadway, NSW 2007 Australia

Tel: +61 29514 3583; Email: James.Wakefield@ uts.edu.au 


\title{
How does students' general academic achievement moderate the implications of social networking on specific levels of learning performance?
}

\begin{abstract}
This study examines to what extent the use of social networking sites impacts different levels of learning. In particular, we examine how post-secondary students' general academic achievement, reflected by grade point average scores, moderate these impacts. The impacts of social networking noted in the literature vary considerably, with positive and negative implications on student learning noted. Examining the moderating effects of students' general academic achievement may address the reasons for such inconsistency in impacts observed. To better understand the implications of social networking on student learning, we examine the implications of student time spent in total on Facebook and on different reasons for using Facebook through a series of ordinary least squares (OLS) regressions. The data on students' social networking use is collected via a survey and data retrieved from institution records on student performance. The context of this study is a first year equation and problem solving centric subject, consistent with the subject matter emphasised in business and STEM disciplines. The findings indicate social networking use puts students at risk who are generally lower academic achievers; in particular their performance is lower across the least difficult levels of learning performance with greater Facebook use. In contrast the performance of higher academic achievers is not significantly impacted. The findings highlight the importance of considering students' general academic achievement as a moderator of the relationship between social networking use and learning performance, and also the importance of considering the impact on specific levels of learning.
\end{abstract}

Keywords: Human-computer interface, media in education, pedagogical issues, post-secondary education 


\section{Highlights}

- Students' general academic achievement moderates the effects of social networking

- Low achieving students are at risk of more severe effects of using social networking

- Social networking effects vary across different learning levels 


\section{Introduction}

This study comes at a time in higher education when students are constantly connected online and devote significant attention to social networking sites (SNSs) (Lau, 2017). For post-secondary education, the rise of SNSs should be of special interest as one of the most popular sites, Facebook, was originally designed, developed and targeted to university networks and college populations. Within two years of its launch in 2004, a study at one US university found $95 \%$ of first year students surveyed knew of Facebook, while 84\% were registered users (Lampe, Ellison, \& Steinfeld, 2006). While some studies suggest that students may be navigating away from SNSs towards more private networks in chat applications (Anderson \& Jiang, 2018), SNSs are still heavily used by the 17 - 32 year old age bracket (Sampasa-Kanyinga, Hamilton, \& Chaput, 2018), the age bracket within which students generally enrol in post-secondary education.

\subsection{Use of social networking in education and associated theory}

Despite the pervasive use of SNSs among the student cohort, the response from postsecondary educators has been mixed, reflecting wider debates around the use and impact of technology within education. Some educators have leaned towards embracing new technologies to align with the perceived needs of 'Digital Natives' (Prensky, 2010). Decentralised learning configurations facilitated by SNSs can provide learning environments supporting personal choice, customisation and consistent with student familiarity (Ebrahim, Ezzadeen, \& Alhazmi, 2015; Hoffman, 2009). This is aligned with the view that education has always been inexorably linked to tools, digital and otherwise, through which knowledge is accessed, shared and constructed (Laurillard, 2016). Conceptually, social networking aligns with educational philosophies such as constructivism (see Dewey, 1966; Vygotsky \& Cole, 1978), that recognise learning is not a passive and solitary process of transmission, but a process whereby the learner actively constructs meaning 
through cognitive, interpretive and social behaviours (Spender, 1996). Theoretically it therefore appears that the use of SNSs can align with student-centred pedagogies, consistent with academics' search for ways to apply SNSs to improve student engagement and performance (Evans, 2013; Hamid, Waycott, Kurnia, \& Chang, 2015; Manca \& Ranieri, 2016; Stone, Fiedler, \& Kandunias, 2014).

While some educators embrace new technologies, others continue the 'well established trend towards non-adoption' (Roblyer, McDaniel, Webb, Herman, \& Witty, 2010) and there are those who seek to ban technology from the classroom altogether (Bowen, 2012). The shift away from the established authority of traditional media and communication channels makes legitimacy, reliability and authenticity less certain. Most recently, 'fake news', online shaming and bullying, and the tendency for social networking to support performative online behaviours and curated social content demonstrate some of the risks of the collective (Lazer, et al., 2018; Nagle, 2018). Within this stimuli intensive environment, relating to both students' studies and use of SNSs, there is the strong possibility of conflicts in students' attention and additional cognitive load, that is not relevant to students' studies, consistent with the indications of distraction-conflict theory (Feng, Wong, Wong, \& Hossain, 2019; Sanders, Baron, \& Moore, 1978). Accordingly, given the varying willingness of educators to embrace SNSs, it is important to consider empirical evidence so educators know what the effects of social networking are on learning and whether students really 'need more time online?'(Ezell, 2016, p. 37). Such evidence is required to understand the baseline effects prior to considering the incorporation of SNS use in course delivery. As part of understanding these baseline effects it is important to recognise that participation both within and across different SNSs is not always equal (Junco, 2013). 


\subsection{Current state of literature}

Consistent with theoretical perspectives associated with social media and the extent educators are willing to embrace social media, noted above, there are a large number of studies providing empirical evidence on the implications of SNS use on student learning (Huang, 2018). Some studies claim there are positive impacts on academic performance (Ainin, Naqshbandi, Moghavvemi, \& Jaafar, 2015; Eid \& Al-Jabri, 2016; Khan, Kend, \& Robertson, 2016). It has been widely recognised that the use of SNSs can improve communication and collaboration within and outside the university community (Gikas \& Grant, 2013; Roblyer, et al., 2010). Accordingly, it claimed that the use of SNSs can help build social networks and increase social interaction, thereby positively effecting performance (Huang, 2018). Some studies claim there are negative impacts on academic performance (Hollis \& Was, 2016; Karpinski, Kirschner, Ozer, Mellott, \& Ochwo, 2013; Wu \& Cheng, 2019). Several studies have found social networking distraction problematic (Fox, Rosen, \& Crawford, 2009; Gikas \& Grant, 2013; Junco, 2012a), with large sample analysis finding that multitasking, especially interactive technologies such as those available through Facebook and messaging while studying, to be negatively related to performance, as measured by grade point average (GPA) (Fox, et al., 2009; Junco, 2012a). It appears the use of SNSs replaces study time, leading to lower performance (Huang, 2018). In situations where SNSs have been incorporated within courses for educational purposes the negative implications may not be as pronounced or apparent, however it is clear that the benefits of increasing SNS adoption within education remains debatable and very much mixed (Alwagait, Shahzad, \& Alim, 2015; Junco, 2012b, 2014; Junco, Elavsky, \& Heiber, 2012; Rosen, Carrier, \& Cheever, 2013).

Despite the underlying reasons for positive and negative implications of SNS use noted in literature, there is no doubt these implications within the post-secondary educational context are 
very mixed, likely resulting from different moderating ${ }^{1}$ variables across different studies (Huang, 2018). One important moderator, which has not received significant attention to date in the context of social networking performance implications, is students' general academic achievement over the course of their studies reflected by measures such as grade point average (GPA). Students exhibit different degrees of aptitude, commitment, dedication, and motivation in different subjects (Beattie \& Thiele, 2016; Mollborn \& Hoekstra, 2010), with students' general academic achievement a reflection of these across their studies. Students' general academic achievement over the course of their studies has been shown to moderate the effectiveness of teaching and learning activities (He, Holton, \& Farkas, 2018), and by extension may moderate the implications of social networking on certain areas of student performance. We speculate the moderating effect of general academic achievement might be especially pertinent to subjects, such as introductory accounting, where students have different degrees of commitment, intrinsic interest and engagement with the subject (Jackling, De Lange, Phillips, \& Sewell, 2012; Marriott \& Marriott, 2003; McGuigan \& Weil, 2011), which may amplify the moderating effects of students' general academic achievement on the association between SNS use and introductory accounting performance. Within such compulsory subjects, a large proportion of students do not consider the subject consistent with their future career plans or what they wish to study - at least initially (Phang, Johl, \& Cooper, 2014). The potentially disruptive nature of SNSs on less than enthusiastic students is potentially problematic and may have significant implications on their performance in this subject.

A range of proxies for use of SNSs and associated performance are used in prior literature, with surveys the most commonly used data collection instrument (Fox, et al., 2009; Junco, 2015;

\footnotetext{
${ }^{1}$ A moderating variable is a variable that affects the relationship between a dependent and independent variable, such that the relationship between these may vary across different levels of the moderating variable.
} 
Junco, Heiberger, \& Loken, 2011; Lau, 2017). Work by Junco (2013) demonstrates respondent self-reporting can be used to approximate time spent across different reasons for using a single SNS, such as Facebook. Distinguishing between different reasons is important as social networking has expanded from its origins of contact between individuals and social groups, to include ever more diverse and convergent uses and purposes, which largely do not appear to be independently measured from a time perspective in existing literature (Huang, 2018). There is also the need for more refined measures of performance than GPA, which while capturing general academic achievement does not focus on specific levels of learning, such as that related to the introductory accounting subject we consider in this study, that may be uniquely effected by the use of SNSs. More refined performance measures will provide the opportunity for research into the use of SNSs to answer more nuanced questions relating to the impacts on different levels of learning (Huang, 2018; Wakefield, Frawley, Tyler, \& Dyson, 2018).

\subsection{Research question}

There is wide variation in the implications of SNS use noted in literature, likely resulting from a range of moderating factors and proxies for SNS use and student performance. In order to make sense of these results, this study addresses the research question as to what extent the use of SNSs affects different levels of student learning, relating to Bloom's taxonomy of learning (Krathwohl, 2002), and specifically how does students' general academic achievement moderate these affects. General academic achievement is known to vary considerably across a student cohort, particularly for those enrolled in compulsory first year subjects in business, STEM (science, technology, engineering and mathematics) and other equation and problem solving based disciplines (Van Soom \& Donche, 2014). In this study, we focus our examination on Facebook and the implications of different reasons for using Facebook. The reasons for using Facebook are 
extensive; however, there is little consideration of the implications of these different reasons on different levels of learning in extant literature. Accordingly, we provide a more detailed understanding of the implications SNSs, addressing some of the inconsistent findings noted in literature (Huang, 2018).

\section{Method}

\section{$2.1 \quad$ Context}

We conduct a cross-sectional survey of all students studying undergraduate introductory accounting at a large metropolitan Australian university, across the Autumn 2017, Spring 2017 and Autumn 2018 teaching sessions. Given there are multiple correct ways of solving a single problem in undergraduate introductory accounting, we argue the findings are applicable to business, STEM and other equation and problem based disciplines. The subject studied is compulsory for students enrolled across a range of degrees including business, commerce, law, engineering, science and information technology. Students studying the subject are typically quite young, with an average age in our study sample 19.60 years, often completing the subject in their first year of study. This provides insights into recently commencing and continuing students' SNS use, who are very much immersed in a world of social networking (Hew, 2011; Kaya \& Bicen, 2016; Magro, Sharp, Ryan, \& Ryan, 2013).

\subsection{Survey}

The survey contains a series of questions focusing on reasons students' use of Facebook. The survey questions we use are provided in Appendix 1. We followed guidance from Dillman (2000) when designing the survey to maximise response rates ${ }^{2}$. A pilot version of the survey was

\footnotetext{
${ }^{2}$ The survey instrument is available via request from the authors.
} 
tested with a small group of 22 students who were studying introductory accounting in intensive mode in early 2017. This allowed the researchers to check the reliability of the online survey, analyse pilot responses to refine the questions, and observe general trends in responses about SNS use. The pilot survey responses are not used in our regression analysis in this paper given the survey questions were subsequently refined post pilot to improve the interpretability and accuracy of the responses provided.

Students were notified of the upcoming survey in the week prior to release during lectures, tutorials and via an announcement on the learning management system. Students were sent an survey invitation email, individually and personally addressed to each of them to maximise response rates and in the following week received two reminders to complete the survey.

\subsection{Regression model and measures}

To examine the implications of social networking on students' introductory accounting performance, we run a series of ordinary least squares (OLS) regressions ${ }^{3}$ using IBM SPSS Version 25 based on the following model:

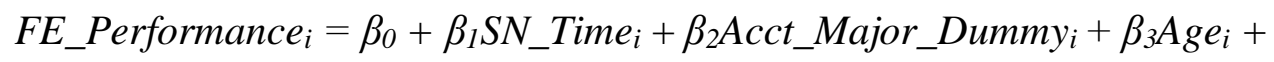

$$
\beta_{4} \text { Gender_Dummy } i+\beta_{5} W A M_{i}+\beta_{6} Y e a r \_S t u d y_{i}+\varepsilon_{i}
$$

- The dependent performance variables (FE_Performance $\left.{ }_{i}\right)$ are based on final examination (FE) performance. The advantage of using data on students' actual performance is it mitigates concerns of self-reporting bias (Khan, et al., 2016). Students receive the same final examination paper across the subject, facilitating consistent performance measurement. There are a series of final examination sections we individually consider for

\footnotetext{
${ }^{3}$ All the variables we use in this study are normalised where necessary, consistent with the assumptions of OLS regression.
} 
performance measurement and accordingly run separate regressions for each. These sections vary in terms of learning difficulty levels, facilitating a more thorough consideration of social networking performance implications. We differentiate the learning difficulty levels based on Bloom's taxonomy of learning from understanding, application, analysis to evaluation (Krathwohl, 2002). We do not differentiate the sections based on the extent students are required to remember, as this applies to all sections, or create as this is beyond the subject difficulty. The final examination sections used as the basis of the dependent variables, in order of the learning difficulty (least to most), are as follows:

- Decision marking (understanding and application learning difficulty): requires the identification and recognition of relevant accounting information and basic problems to be solved using information in the context of costing and long-term qualitative considerations.

- Cost volume profit analysis (understanding and application learning difficulty): requires identification and recognition of relevant accounting information and basic problems to be solved using this information in the context of basic cost volume profit analysis, 'what if' scenarios, multiple product settings, and organisations seeking to improve profitability.

- Financial accounting (understanding, application and analysis learning difficulty): requires the identification and recognition of relevant accounting information, implementation of accounting processes and basic examination of information available, in the context of recording journal and adjusting entries, and the calculation and interpretation of ratios. 
- Activity based costing (application to analysis learning difficulty): requires complex problem solving, distinguishing and comparing different costing techniques concerning activity based costing calculations and traditional overhead allocation and the consideration of the value relevance of activity based costing.

- Earnings management (evaluation learning difficulty): requires judgement of current accounting practices and the selection and presentation of an argument justifying more appropriate alternatives in the context of a written case.

- The independent variables are:

- SN_Time $i$ : This variable is calculated by multiplying the total time (minutes per day) students spend on social networking, focusing on Facebook (survey question 1, reported in Appendix 1) by the extent and likelihood students indicate for different reasons for using Facebook (survey questions 2 and 3, reported in Appendix 1). These reasons for using Facebook are split into two categories of indicators; first general reasons (question 2) and second specific university study reasons (question 3). To proxy for the relative time students spend on different reasons for using Facebook, we multiply students' time on Facebook (survey question 1) by the Likert scale responses relating to the reasons for using Facebook (survey questions 2 and 3). Higher Likert scale response values (ranging from $1-$ 5) indicate greater extent and likelihood of using Facebook for a particular reason. Our regression model is re-run in turn to include each of the resultant $S N_{-} T_{i m e}$ variables separately, to avoid multicollinearity issues given the expected correlated nature of these variables. The self-reported nature of time spent on SNSs is established as a means of approximating this variable (Junco, 2013) 
- Acct_Major_Dum : Control variable assigned 1 for students who plan to major in accounting, 0 otherwise. Students planning to undertake an accounting major may exhibit greater motivation to succeed in introductory accounting (McGuigan \& Weil, 2011), impacting their examination performance.

- $\quad \operatorname{Age}_{i}$ : Age at the time of studying introductory accounting. Research finds student age is a significant predictor of improved examination performance (Edmonds \& Edmonds, 2008).

- Gender_Dummy ${ }_{i}$ : Assigned 1 for male, 0 for female students. While findings are mixed, some studies indicate gender is associated with different learning approaches and performance (Schleifer \& Dull, 2009).

- $W A M_{i}$ : The weighted average mark (WAM) is based on the final grade in all university subjects students have studied up to, but excluding introductory accounting. The WAM variable is the equivalent of GPA in this study. Past student performance, in terms of general academic achievement, has consistently been shown to be a predictor of future performance (Crawford \& Wang, 2014; Duff, 2004). While some studies have used university entry grades (ATAR in the Australian context) as a control variable for student performance, use of entry grades is problematic for a number of reasons. This includes measurement noise resulting from bonus point schemes and a narrow clustering of entry grades at the institution.

- Year_Study $y_{i}$ Year of study relates to the year a student studies the introductory accounting subject. While most students take the subject in first year, given the introductory nature of the subject, some students complete it later in their program 
consistent with different study programs and student preferences. The further a student progresses in their degree, the higher the metacognition scores (Sperling, Howard, Staley, \& DuBois, 2004), and the more likely they are to adopt different learning approaches (Jackling, 2005), leading to higher performance.

\subsection{General academic achievement moderation}

We split the sample based on students' weighted average mark (WAM) across their studies, below and above the median WAM value, to examine whether students' general academic achievement is expected to moderate the effects of social networking exposure on performance. As mentioned in the WAM variable measurement explanation above, students' entry grades, ATAR, are narrowly clustered due to entry requirements at the institution this study was undertaken. Accordingly, while the entry grade is a reflection of student ability, WAM is not only a control and predictor of future performance once enrolled at the institution, but also a reflection students' general academic achievement once enrolled at the institution relative to their fellow students.

\subsection{Survey response}

A total of 505 fully completed surveys were received, equivalent to a $16.73 \%$ response rate. While we hoped for a higher response rate, students were not required to complete the survey as part of their studies, and could only be encouraged to do so, consistent with ethical guidelines. To test for non-response bias, we compare whether there is a significant difference between the mean final examination scores and WAM of students who did and did not complete the survey. The $T$-tests indicate students who are generally higher performing, based on final examination scores and WAM, were more likely to complete the survey. While the difference is significant, it is not substantial and therefore our comparison between relatively low and high general academic 
achievement, for the purpose of moderation testing, is still meaningful. Further, consistent with the results we present below, we believe a higher proportion of more highly performing students biases against finding the negative and significant effects of social networking on student performance we observe, reinforcing the significance of these effects. We also test for nonresponse bias by comparing early and late survey respondents' mean time spent on social networking, by identifying students who responded after reminders were sent to complete the survey. Comparison of the early and late responses is consistent with non-response bias testing in the literature (Armstrong \& Overton, 1977). The $T$-test indicates early and late respondents to the survey did not significantly differ, at the 5\% significance level, based on the mean time spent on Facebook in total and on the different reasons for using Facebook. Accordingly, based on the testing reported above, we believe non-response bias is not a concern.

\subsection{Descriptive statistics}

The descriptive statistics and frequencies for the variables detailed above are reported in Table 1 below. The descriptive statistics indicate sufficient variation for the purpose of the regression analysis. Consistent with the heavy use of SNSs noted in prior literature (Pew Research Center, 2016), students reported average Facebook use of 116.64 minutes per day.

\section{[INSERT TABLE 1 HERE]}

The extent and likelihood of reasons for generally using Facebook and specific university study reasons for using Facebook respectively are reported in Table 2 Panel A and B respectively below. We report the percentage of respondents selecting each of the Likert scale indicators for each reason for using Facebook and the mean score on the 1-5 Likert scale in the second last column. The uses are ranked in the table from highest to lowest (mean) use. As previously noted, 
the self-reporting of time students spend on SNSs is established as a valid means of approximating SNS use (Junco, 2013); however, we recognise the additional requirement to recall extent and likelihood of reasons for using Facebook imposes a higher recall complexity on respondents. We believe that focusing our survey questions on Facebook, which is frequently and repetitively used, and asking respondents to identify the extent and likelihood of different reasons for use within the granularity of a five point Likert scale, reduces the recall and response complexity. To provide assurance that respondents were not simply indicating the same and/or very similar responses to survey questions, we run Harman's single-factor common method bias test. The analysis of the 13 indicators relating to reasons for using Facebook identified three factors with eigenvalues greater than one, with the strongest factor explaining $40.24 \%$ of the total variance. This suggests a single source bias and preference when answering survey questions is not present (Podsakoff \& Organ, 1986).

\section{[INSERT TABLE 2 HERE]}

As explained above, to proxy for the time students spent on different reasons for using Facebook, we multiply students' time on Facebook by the Likert scale indicator values for each reason for use, summarised in Table 2 above. The descriptive statistics for these resultant variables are reported in Table 3 below. Consistent with the variables used to create these measures, and the lack of common method response bias to survey questions, there is considerable variation in the resultant measures.

[INSERT TABLE 3 HERE] 


\section{Results and discussion}

The results in this section are presented as follows. First, we present the results based on the full sample in Table 4. Second, to examine the moderating effects of students' general academic achievement on specific levels of learning, the low and high WAM sub-sample results are presented in Table 5, Panel A and B respectively. Given the large number of regressions run for the purpose of examining the implications of social networking time on the five dependent performance variables, only the independent variable coefficients of interest (time variables) are summarised in Tables 4 and 5 for ease of view and comparison. To illustrate the results concerning the other independent (control) variable coefficients, $F$-statistics and adjusted $R$-square values, a sample ${ }^{4}$ of the full regressions is reported in Appendix 2. These sample results relate to the regression models including total social networking time and relative time on education and study and asking a classmate for help in class (Appendix 2 Table A.1) and low and high WAM subsamples (Appendix 2 Table A.2). The results concerning the other independent, control, variable coefficients, $F$-statistics and adjusted $R$-square values are highly consistent across all regression models. The regression results indicate the regression models are significant, based on the $F$ statistic, and explain a substantial proportion of the variation in performance, based on the $R$ square values. The only exception is the $F$-statistic is not significant for the activity based costing (apply and analyse) dependent variables models in the low WAM sample, indicating a lack of notable effects in these regression models.

[INSERT TABLE 4 AND 5]

\footnotetext{
${ }^{4}$ Given the extensiveness of the results tabled in this paper and in the interests of keeping the paper to an acceptable length, the full regression results are not reported but are available from the authors upon request.
} 
These full sample results generally indicate total time on Facebook is related to significantly lower performance in the least difficult levels of learning (understanding and application). Of particular concern is students who are generally lower academic achievers, our low WAM sub-sample, drive this result, indicating these students are the ones who are specifically negatively impacted by the disruptive nature of Facebook (Fox, et al., 2009; Gikas \& Grant, 2013; Junco, 2012a). The relative time spent on a range of reasons for using Facebook has clear implications on student performance, for lower academic achievers, regardless of whether these uses are university study or non-study related. These negative implications are universally observed across the least difficult levels of learning (understanding, application and analysing). This provides greater insight into how distractive SNSs are across a range of diverse uses, building on prior literature (Fox, et al., 2009; Gikas \& Grant, 2013; Huang, 2018; Junco, 2012a).

Facebook use appears to have little effect on performance concerning more difficult levels of learning, relating to application, analysing and evaluation (activity based costing and earnings management examination sections in this study). This suggests students who are generally lower academic achievers may perform consistently poorly in such levels of learning and therefore the negative implications are only observed in less difficult levels of learning.

The variation of our results across different levels of learning difficulty and students' general academic achievement explains the conflicting results concerning the impact of SNS use on student performance noted in prior literature (Ainin, et al., 2015; Eid \& Al-Jabri, 2016; Hollis \& Was, 2016; Huang, 2018; Karpinski, et al., 2013; Khan, et al., 2016). Our results are quite concerning as many academics attempt to use SNSs, such as Facebook, to engage students in introductory compulsory subjects, many of which are in business and STEM, where students' initial subject enthusiasm is low and motivation levels are problematic, without discipline specific 
guidelines (Stone, et al., 2014). Our results indicate at risk students, who already have lower general academic achievement across their university studies, are further distracted by Facebook. Some may argue that student interaction with a group on Facebook for course completion purposes is useful (Sharples, 2000, 2002); however the negative implications of university related Facebook use are similar to non-university related use.

\section{$3.1 \quad$ Further testing}

To examine the implications of SNS use more broadly, we also measure the time students spend on a number of frequently used, but generally less time intensive, SNSs - LinkedIn, Snapchat and Twitter (survey question 4, reported in Appendix 1). This further testing allows the extent of Facebook pervasiveness and impacts to be gauged against other SNSs. It is noted in existing literature that separate effects of SNSs on student performance are rarely reported (Huang, 2018), and accordingly we address this here. Our results across the full sample, low and high general academic achievement sub-samples and the five levels of specific learning performance variables, indicate time spent on LinkedIn, Snapchat and Twitter has virtually no significant impact on student performance of any kind. ${ }^{5}$ This highlights the impactful nature of time spent on Facebook compared with other SNSs, consistent with the focus in this study.

Further to the subsample testing reported above, we also vary the regression model for the purpose of sensitivity testing. We vary the regression model by using WAM as the dependent variable and include final examination grade in introductory accounting as an independent variable controlling for student ability. We also split the sample based on median introductory accounting final examination grade, creating low and high final examination subsamples. This sensitivity test

\footnotetext{
${ }^{5}$ Given the extensiveness of the results tabled in this paper and in the interests of keeping the paper to an acceptable length, the sensitivity testing results are not reported here but are available from the authors upon request.
} 
allows the examination of the uniqueness of our findings in the context of introductory accounting, a compulsory introductory equation and problem based subject similarly to those in business and STEM subjects, compared with those relating to students' general academic achievement, which includes a wide mix of subjects. The regression results indicate the implications of student time spent on Facebook and associated Facebook uses on WAM is insignificant in all cases. This sensitivity testing indicates our findings are unique to the introductory accounting context, and similarly equation and problem based learning subjects in business and STEM subjects. This finding also indicates it is important to consider the implications of social networking on a context by context basis, and not to generalise the findings to the wider populations of students ${ }^{6}$.

\section{Conclusion}

Our research highlights that the use of SNSs puts poor performing students at risk in their university studies (based on our low student WAM sub-sample). Greater use of Facebook will very likely lead to lower results in compulsory introductory accounting, business and STEM related subjects with similar learning characteristics, for lower general academically achieving students. In particular, lower achieving students who spend more time on Facebook and using Facebook for a range of university study and non-study purposes are likely to perform worse in subjects with lower learning difficulty; this may lead to further learning issues if these students enrol in more advanced subjects at a later stage. Considering the variation in implications across different student groups, based on general academic achievement, highlights the importance of understanding how different students interact with SNSs (Roblyer \& Wiencke, 2004), helping to provide a more informed approach to considering whether to use SNSs for educational purposes.

\footnotetext{
${ }^{6}$ Given the extensiveness of the results tabled in this paper and in the interests of keeping the paper to an acceptable length, the sensitivity testing results are not reported here but are available from the authors upon request.
} 
The findings from this study highlight that using SNSs as part of teaching and learning interventions in the pursuit of improving student engagement and performance needs to be very carefully considered and examined (Evans, 2013; Hamid, et al., 2015; Manca \& Ranieri, 2016; Stone, et al., 2014). Our findings suggest the use of SNSs to support learning needs to be done in a way that carefully considers how and why students engage with SNSs, consistent with student aptitude, commitment, dedication, motivation, and general academic achievement. Efforts need to be taken to ensure educational embedding of SNS technologies does not inadvertently disadvantage weaker students, which certainly appears likely given our findings, and favour stronger students.

\subsection{Limitations and future research opportunities}

There are a number of limitations of this study and associated research opportunities to address. First, we while we argue our findings in the context of undergraduate introductory accounting are applicable to equation and problem based business and STEM subjects, further research is necessary to confirm this is the case. It is important to recognise that factors including student motivation, self-efficacy, self-determination and self-regulation varies across different subjects and student cohorts. Research relating to individual disciplines and student cohorts is necessary to confirm the generalisability of our findings. Second, while we believe our findings are applicable in the current teaching and learning landscape, given the data we analyse was very recently collected, there is no doubt student, and also instructor, use of technology and reasons for using technology continues to evolve. Accordingly, the relevance of the findings need to be considered moving forward, particularly as social networking platforms and associated functions are released and evolve. For example, it appears Instagram has been more heavily used recently, reflective of responses to an open-ended survey question we ask on what 'other' SNSs students 
use (survey question 5, reported in Appendix 1), which we did not expect when administering the survey. Finally, we assume that social networking use has linear performance implications. Given the extensive nature of the regressions presented in this study, we do not explore the possibility non-linear performance implications and accordingly there is scope in future research to examine this possibility. 
Acknowledgements: We would like to thank the student participants who completed the survey, acknowledge the valuable feedback received from the Computers \& Education editor, Professor Chin-Chung Tsai, and three anonymous reviewers, the 2018 European Accounting Association Annual Congress and 2018 UTS Accounting Discipline Group Seminar Series participants, and the UTS Business School Accounting Discipline Group teaching staff who provided feedback on the pilot survey. We would also like to acknowledge and thank Madison Reynolds for her research assistance on this project.

\section{Declarations of interest: none}

Funding: This research did not receive any specific grant from funding agencies in the public, commercial, or not-for-profit sectors. 


\section{References}

Ainin, S., Naqshbandi, M. M., Moghavvemi, S., \& Jaafar, N. I. (2015). Facebook usage, socialization and academic performance. Computers \& Education, 83, 64-73.

Alwagait, E., Shahzad, B., \& Alim, S. (2015). Impact of social media usage on students academic performance in Saudi Arabia. Computers in Human Behavior, 51(Part B), 1092-1097.

Anderson, M., \& Jiang, J. (2018). Teens, social media \& technology 2018. Pew Research Center, 31 .

Armstrong, J. S., \& Overton, T. S. (1977). Estimating nonresponse bias in mail surveys. Journal of marketing research, 14(3), 396-402.

Beattie, I. R., \& Thiele, M. (2016). Connecting in class? College class size and inequality in academic social capital. The Journal of Higher Education, 87(3), 332-362.

Bowen, J. E. (2012). Teaching naked: how moving technology out of your college classroom will improve student learning. San Francisco, CA: John Wiley \& Sons.

Crawford, I., \& Wang, Z. (2014). Why are first-year accounting studies inclusive? Accounting \& Finance, 54(2), 419-439.

Dewey, J. (1966). Democracy and Education: an introduction to the philosophy of education. New York: Free Press.

Dillman, D. (2000). Mail and internet surveys: The tailored design method. New York ; Chichester: John Wiley.

Duff, A. (2004). Understanding academic performance and progression of first-year accounting and business economics undergraduates: the role of approaches to learning and prior academic achievement. Accounting Education, 13(4), 409-430. 
Ebrahim, H. S., Ezzadeen, K., \& Alhazmi, A. (2015). Acquiring knowledge through mobile applications. International Journal of Interactive Mobile Technologies, 9(3).

Edmonds, C. T., \& Edmonds, T. P. (2008). An empirical investigation of the effects of SRS technology on introductory managerial accounting students. Issues in Accounting Education, 23(3), 421-434.

Eid, M. I. M., \& Al-Jabri, I. M. (2016). Social networking, knowledge sharing, and student learning: The case of university students. Computers \& Education, 99, 14-27.

Evans, C. (2013). Twitter for teaching: Can social media be used to enhance the process of learning? British Jounral of Education Technology, 45(5), 902-915.

Ezell, P. (2016). To Like or Not to Like: Facebook in the higher education classroom. Journal of Teaching and Learning with Technology, 5(1), 33-45.

Feng, S., Wong, Y. K., Wong, L. Y., \& Hossain, L. (2019). The Internet and Facebook Usage on Academic Distraction of College Students. Computers \& Education, 134, 41-49.

Fox, A. B., Rosen, J., \& Crawford, M. (2009). Distractions, Distractions: Does instant messaging affect college student's performance on a concurrent reading comprehension task. Cyberpsychology, Behaviour and Social Networking, 12(1), 51-53.

Gikas, J., \& Grant, M. M. (2013). Mobile computing devices in higher education: Student perspectives on learning with cellphones, smartphones \& social media. The Internet and Higher Education, 19, 18-26.

Hamid, S., Waycott, J., Kurnia, S., \& Chang, S. (2015). Understanding students' perceptions of the benefits of online social networking use for teaching and learning. The Internet and Higher Education, 26, 1-9. 
He, W., Holton, A. J., \& Farkas, G. (2018). Impact of partially flipped instruction on immediate and subsequent course performance in a large undergraduate chemistry course. Computers \& Education, 125, 120-131.

Hew, K. F. (2011). Students' and teachers' use of Facebook. Computers in Human Behaviour, 27(2), 662-676.

Hoffman, E. (2009). Social media and learning environments: Shifting perspectives on the locus of control. Technology \& Social Media, 15(2), 1-8.

Hollis, R. B., \& Was, C. A. (2016). Mind wandering, control failures, and social media distractions in online learning. Learning and Instruction, 42, 104-112.

Huang, C. (2018). Social network site use and academic achievement: A meta-analysis. Computers \& Education, 119, 76-83.

Jackling, B. (2005). Analysis of the learning context, perceptions of the learning environment and approaches to learning accounting: a longitudinal study. Accounting \& Finance, 45(4), 597-612.

Jackling, B., De Lange, P., Phillips, J., \& Sewell, J. (2012). Attitudes towards accounting: Differences between Australian and international students. Accounting Research Journal, 25(2), 113-130.

Junco, R. (2012a). In-class multitasking and academic performance. Computers in Human Behavior, 28(6), 2236-2243.

Junco, R. (2012b). The relationship between frequency of Facebook use, participation in Facebook activities, and student engagement. Computers \& Education, 58(1), 162-171.

Junco, R. (2013). Comparing actual and self-reported measures of Facebook use. Computers in Human Behavior, 29(3), 626-631. 
Junco, R. (2014). iSpy: seeing what students really do online. Learning , Media and Technology, 29(1), 75-89.

Junco, R. (2015). Student class standing, Facebook use, and academic performance. Journal of Applied Developmental Psychology, 36(1), 18-29.

Junco, R., Elavsky, C. M., \& Heiber, G. (2012). Putting Twitter to the test: Assessing outcomes for student collaboration, engagement and success. British Journal of Educational Technology, 44(2), 273-287.

Junco, R., Heiberger, G., \& Loken, E. (2011). The effect of Twitter on college student engagement and grades. Journal of Computer Assisted Learning, 27(2), 119-132.

Karpinski, A. C., Kirschner, P. A., Ozer, I., Mellott, J. A., \& Ochwo, P. (2013). An exploration of social networking site use, multitasking, and academic performance among United States and European university students. Computers in Human Behavior, 29(3), 11821192.

Kaya, T., \& Bicen, H. (2016). The effects of social media on students' behaviors; Facebook as a case study. Computers in Human Behavior, 59, 374-379.

Khan, T., Kend, M., \& Robertson, S. (2016). Use of social media by university accounting students and its impact on learning outcomes. Accounting Education, 26(6), 534-567.

Krathwohl, D. R. (2002). A revision of Bloom's taxonomy: An overview. Theory into practice, 41(4), 212-218.

Lampe, C., Ellison, N. B., \& Steinfeld, C. (2006). A face(book) in the crowd: social searching vs. social browsing. In CSCW'06: Proceedings of the 2006 20th anniversary conference on Computer supported cooperative work (pp. 167-170). Banff, Alberta, Canada: ACM. 
Lau, W. W. (2017). Effects of social media usage and social media multitasking on the academic performance of university students. Computers in Human Behavior, 68, 286-291.

Laurillard, D. (2016). Teaching as a design science: building pedagogical patterns for learning and technology. London: Routledge, Taylor and Francis Group.

Lazer, D. M., Baum, M. A., Benkler, Y., Berinsky, A. J., Greenhill, K. M., Menczer, F., Metzger, M. J., Nyhan, B., Pennycook, G., \& Rothschild, D. (2018). The science of fake news. Science, 359(6380), 1094-1096.

Magro, M. J., Sharp, J. H., Ryan, K., \& Ryan, S. D. (2013). Investigating ways to use Facebook at the university level: A delphi study. Issues in Informing Science and Information Technology, 10.

Manca, S., \& Ranieri, M. (2016). Facebook and the others. Potentials and obstacles of social media for teaching in higher education. Computers \& Education, 95, 216-230.

Marriott, P., \& Marriott, N. (2003). Are we turning them on? A longitudinal study of undergraduate accounting students' attitudes towards accounting as a profession. Accounting Education, 12(2), 113-133.

McGuigan, N., \& Weil, S. (2011). Addressing a 'preconceptual threshold': A transformation in student preconceptions of introductory accounting. Critical Perspectives on Communication, Cultural and Policy Studies, 30(2), 15-33.

Mollborn, S., \& Hoekstra, A. (2010). "A meeting of minds" using clickers for critical thinking and discussion in large sociology classes. Teaching Sociology, 38(1), 18-27.

Nagle, J. (2018). Twitter, cyber-violence, and the need for a critical social media literacy in teacher education: A review of the literature. Teaching and Teacher Education, 76, 8694. 
Pew Research Center. (2016). Social Media Update 2016. In. Washington, USA: Pew Research Centre.

Phang, M. M. S., Johl, S. K., \& Cooper, B. J. (2014). Goal-efficacy framework: An examination of domestic and international accounting students' academic performance. Accounting and Finance, 54(4), 1295-1318.

Podsakoff, P. M., \& Organ, D. W. (1986). Self-reports in organizational research: Problems and prospects. Journal of Management, 12(4), 531-544.

Prensky, M. (2010). Teaching digital natives: partnering for real learning. Thousand Oaks: Corwin.

Roblyer, M. D., McDaniel, M., Webb, M., Herman, J., \& Witty, J. V. (2010). Findings on Facebook in higher education: A comparison of college faculty and student uses and perceptions of social networking sites. The Internet and Higher Education, 13(3), 134140.

Roblyer, M. D., \& Wiencke, W. R. (2004). Exploring the interaction equation: Validating a rubric to assess and encourage interaction in distance courses. Journal of Asynchronous Learning Networks, 8(4), 24-37.

Rosen, L. D., Carrier, L. M., \& Cheever, N. A. (2013). Facebook and texting made me do it: Media-induced taks-switching while studying. Computers in Human Behavior, 29(3), 948-958.

Sampasa-Kanyinga, H., Hamilton, H. A., \& Chaput, J. P. (2018). Use of social media is associated with short sleep duration in a dose-response manner in students aged 11 to 20 years. Acta Paediatrica, 107(4), 694-700. 
Sanders, G. S., Baron, R. S., \& Moore, D. L. (1978). Distraction and social comparison as mediators of social facilitation effects. Journal of Experimental Social Psychology, 14(3), 291-303.

Schleifer, L. L., \& Dull, R. B. (2009). Metacognition and performance in the accounting classroom. Issues in Accounting Education, 24(3), 339-367.

Sharples, M. (2000). The design of personal mobile technologies for lifelong learning. Computers \& Education, 34(3), 177-193.

Sharples, M. (2002). Disruptive devices: mobile technology for conversational learning. International Journal of Continuing Engineering Education and Life Long Learning, 12(5/6), 504-520.

Spender, J.-C. (1996). Organizational knowledge, learning and memory: three concepts in search of a theory. Journal of organizational change management, 9(1), 63-78.

Sperling, R. A., Howard, B. C., Staley, R., \& DuBois, N. (2004). Metacognition and selfregulated learning constructs. Educational Research and Evaluation, 10(2), 117-139.

Stone, G., Fiedler, B. A., \& Kandunias, C. (2014). Harnessing Facebook for student engagement in accounting education: Guiding principles for accounting students and educators. Accounting Education, 23(4), 295-321.

Van Soom, C., \& Donche, V. (2014). Profiling first-year students in STEM programs based on autonomous motivation and academic self-concept and relationship with academic achievement. PloS one, 9(11), e112489.

Vygotsky, L. S., \& Cole, M. (1978). Mind in society : the development of higher psychological processes. Cambridge: Harvard University Press. 
Wakefield, J., Frawley, J. K., Tyler, J., \& Dyson, L. E. (2018). The impact of an iPad-supported annotation and sharing technology on university students' learning. Computers \& Education, 122, 243-259.

Wu, J.-Y., \& Cheng, T. (2019). Who is better adapted in learning online within the personal learning environment? Relating gender differences in cognitive attention networks to digital distraction. Computers \& Education, 128, 312-329. 


\section{APPENDIX 1}

Note: This section provides the survey questions referred to in this paper. Additional information relating to these questions is provided in italics.

Question 1:

On average, about how much time per day do you spend on Facebook? (Respondents select number of both hours and minutes from drop down menus).

Question 2:

Indicate the extent you agree or disagree Facebook is useful for the following things. (Respondents choose from the following Likert scale points for each thing: Strongly agree, Agree, Neither agree nor disagree, Disagree, Strongly disagree).
a. Communications with friends and family
b. Education and study
c. Enjoyment and entertainment
d. Keeping informed about events and news
e. Filling in 'dead' or vacant time
f. Work related reasons

Question 3:

How likely are you to use Facebook for the following things?

(Respondents choose from the following Likert scale points for each use: Very likely, Likely, Neither unlikely or likely, Unlikely and Very unlikely).
a. Arrange a meeting for a group project
b. Ask a classmate for help in the class
c. Help manage a group project
d. Contact another student with a question related to class or university work
e. Discuss university work
f. Arrange a face-to-face study group
g. Collaborate on an assignment in a way my instructor would like

\section{Question 4:}

On average, about how much time per week do you spend on each of the following?

(Respondents select number of both hours and minutes from drop down menus for each of the three applications).
a. Linkedin
b. Snapchat
c. Twitter 


\section{Question 5:}

Please specify any other social media sites or applications you use that are not listed above and how much time per week you spend on each. (Respondents provided with open-ended responses area to type answer). 
APPENDIX 2: TABLE A.1 - Sample regression results: Full sample $(n=505)$

\begin{tabular}{|c|c|c|c|c|c|c|c|c|c|}
\hline \multirow[t]{2}{*}{$\begin{array}{l}\text { Social networking } \\
\text { time }\end{array}$} & \multirow[b]{2}{*}{ Dependent variable } & $\begin{array}{c}\text { Social } \\
\text { networking } \\
\text { time }\end{array}$ & $\begin{array}{c}\text { Accounting } \\
\text { major } \\
\text { dummy }\end{array}$ & Age & $\begin{array}{l}\text { Gender } \\
\text { dummy }\end{array}$ & WAM & $\begin{array}{c}\text { Year of } \\
\text { study }\end{array}$ & \multirow[b]{2}{*}{ F-stat } & \multirow[b]{2}{*}{ Adj. R square } \\
\hline & & \multicolumn{6}{|c|}{ Coefficient ( $t$-stat) } & & \\
\hline \multirow{5}{*}{ Facebook time } & Decision making (understand and apply) & $\begin{array}{l}-0.082 * * \\
(-2.045)\end{array}$ & $\begin{array}{c}0.053 \\
(1.333)\end{array}$ & $\begin{array}{c}0.049 \\
(1.114)\end{array}$ & $\begin{array}{c}0.077^{*} \\
(1.946)\end{array}$ & $\begin{array}{l}0.443 * * * \\
(10.647)\end{array}$ & $\begin{array}{c}0.037 \\
(0.869)\end{array}$ & $21.050 * * *$ & 0.187 \\
\hline & Cost volume profit (understand and apply) & $\begin{array}{l}-0.085^{* *} \\
(-2.200)\end{array}$ & $\begin{array}{c}0.051 \\
(1.324)\end{array}$ & $\begin{array}{c}0.000 \\
(0.006)\end{array}$ & $\begin{array}{l}0.097 * * \\
(2.513)\end{array}$ & $\begin{array}{l}0.483 * * * \\
(11.951)\end{array}$ & $\begin{array}{c}0.037 \\
(0.897)\end{array}$ & $27.580 * * *$ & 0.234 \\
\hline & Financial accounting (understand, apply and analyse) & $\begin{array}{l}-0.060 \\
(-1.626)\end{array}$ & $\begin{array}{c}0.038 \\
(1.049)\end{array}$ & $\begin{array}{l}-0.045 \\
(-1.102)\end{array}$ & $\begin{array}{c}0.016 \\
(0.425)\end{array}$ & $\begin{array}{l}0.554 * * * \\
(14.424)\end{array}$ & $\begin{array}{c}0.034 \\
(0.856)\end{array}$ & $39.870 * * *$ & 0.309 \\
\hline & Activity based costing (apply and analyse) & $\begin{array}{l}-0.040 \\
(-0.963)\end{array}$ & $\begin{array}{c}0.065 \\
(1.581)\end{array}$ & $\begin{array}{c}0.052 \\
(1.131)\end{array}$ & $\begin{array}{c}0.057 \\
(1.390)\end{array}$ & $\begin{array}{l}0.368^{* * * *} \\
(8.520)\end{array}$ & $\begin{array}{c}0.035 \\
(0.785)\end{array}$ & $13.300 * * *$ & 0.124 \\
\hline & Earnings management (evaluate) & $\begin{array}{c}0.027 \\
(0.719) \\
\end{array}$ & $\begin{array}{c}0.038 \\
(1.027) \\
\end{array}$ & $\begin{array}{l}-0.130 * * * \\
(-3.158) \\
\end{array}$ & $\begin{array}{c}0.019 \\
(0.506) \\
\end{array}$ & $\begin{array}{c}0.497 * * * \\
(12.701) \\
\end{array}$ & $\begin{array}{c}0.054 \\
(1.335) \\
\end{array}$ & $35.280 * * *$ & 0.283 \\
\hline \multirow{5}{*}{$\begin{array}{l}\text { Education and } \\
\text { study*FB time }\end{array}$} & Decision making (understand and apply) & $\begin{array}{c}-0.067^{*} \\
(-1.656)\end{array}$ & $\begin{array}{c}0.053 \\
(1.316)\end{array}$ & $\begin{array}{c}0.053 \\
(1.166)\end{array}$ & $\begin{array}{c}0.074 * \\
(1.826)\end{array}$ & $\begin{array}{l}0.452 * * * \\
(10.627)\end{array}$ & $\begin{array}{c}0.036 \\
(0.836)\end{array}$ & $21.032 * * *$ & 0.194 \\
\hline & Cost volume profit (understand and apply) & $\begin{array}{l}-0.090 * * \\
(-2.293)\end{array}$ & $\begin{array}{c}0.045 \\
(1.137)\end{array}$ & $\begin{array}{c}0.013 \\
(0.307)\end{array}$ & $\begin{array}{l}0.085^{* *} \\
(2.165)\end{array}$ & $\begin{array}{l}0.494 * * * \\
(12.001)\end{array}$ & $\begin{array}{c}0.035 \\
(0.838)\end{array}$ & $27.787 * * *$ & 0.244 \\
\hline & Financial accounting (understand, apply and analyse) & $\begin{array}{l}-0.072 * \\
(-1.929)\end{array}$ & $\begin{array}{c}0.030 \\
(0.801)\end{array}$ & $\begin{array}{c}-0.034 \\
(-0.825)\end{array}$ & $\begin{array}{c}0.007 \\
(0.180)\end{array}$ & $\begin{array}{l}0.564 * * * \\
(14.405)\end{array}$ & $\begin{array}{c}0.038 \\
(0.957)\end{array}$ & $39.638 * * *$ & 0.317 \\
\hline & Activity based costing (apply and analyse) & $\begin{array}{l}-0.048 \\
(-1.137)\end{array}$ & $\begin{array}{c}0.053 \\
(1.254)\end{array}$ & $\begin{array}{c}0.067 \\
(1.428)\end{array}$ & $\begin{array}{c}0.059 \\
(1.395)\end{array}$ & $\begin{array}{l}0.381 * * * \\
(8.652)\end{array}$ & $\begin{array}{c}0.022 \\
(0.490)\end{array}$ & $13.805^{* * *}$ & 0.133 \\
\hline & Earnings management (evaluate) & $\begin{array}{c}0.020 \\
(0.511) \\
\end{array}$ & $\begin{array}{c}0.034 \\
(0.890) \\
\end{array}$ & $\begin{array}{l}-0.120 * * * \\
(-2.837)\end{array}$ & $\begin{array}{c}0.010 \\
(0.260) \\
\end{array}$ & $\begin{array}{l}0.507 * * * \\
(12.706)\end{array}$ & $\begin{array}{c}0.050 \\
(1.208)\end{array}$ & $34.768 * * *$ & 0.289 \\
\hline \multirow{5}{*}{$\begin{array}{l}\text { Ask a classmate } \\
\text { for help in the } \\
\text { class*FB time }\end{array}$} & Decision making (understand and apply) & $\begin{array}{l}-0.090^{* *} \\
(-2.189)\end{array}$ & $\begin{array}{c}0.050 \\
(1.233)\end{array}$ & $\begin{array}{c}0.046 \\
(1.021)\end{array}$ & $\begin{array}{c}0.075^{*} \\
(1.848)\end{array}$ & $\begin{array}{l}0.452 * * * \\
(10.665)\end{array}$ & $\begin{array}{c}0.040 \\
(0.919)\end{array}$ & $21.459 * * *$ & 0.197 \\
\hline & Cost volume profit (understand and apply) & $\begin{array}{l}-0.101 * * \\
(-2.542)\end{array}$ & $\begin{array}{c}0.042 \\
(1.065)\end{array}$ & $\begin{array}{c}0.008 \\
(0.190)\end{array}$ & $\begin{array}{l}0.086^{* *} \\
(2.194)\end{array}$ & $\begin{array}{l}0.495 * * * \\
(12.036)\end{array}$ & $\begin{array}{c}0.038 \\
(0.910)\end{array}$ & $28.053 * * *$ & 0.245 \\
\hline & Financial accounting (understand, apply and analyse) & $\begin{array}{l}-0.091 * * \\
(-2.422)\end{array}$ & $\begin{array}{c}0.027 \\
(0.715)\end{array}$ & $\begin{array}{l}-0.040 \\
(-0.966)\end{array}$ & $\begin{array}{c}0.008 \\
(0.202)\end{array}$ & $\begin{array}{l}0.564 * * * \\
(14.454)\end{array}$ & $\begin{array}{c}0.042 \\
(1.043)\end{array}$ & $40.165^{* * *}$ & 0.320 \\
\hline & Activity based costing (apply and analyse) & $\begin{array}{c}-0.074 * \\
(1.740)\end{array}$ & $\begin{array}{c}0.049 \\
(1.175)\end{array}$ & $\begin{array}{c}0.060 \\
(1.287)\end{array}$ & $\begin{array}{c}0.059 \\
(1.410)\end{array}$ & $\begin{array}{l}0.382 * * * \\
(8.679)\end{array}$ & $\begin{array}{c}0.026 \\
(0.568)\end{array}$ & $14.142 * * *$ & 0.136 \\
\hline & Earnings management (evaluate) & $\begin{array}{c}0.034 \\
(0.885) \\
\end{array}$ & $\begin{array}{c}0.036 \\
(0.934) \\
\end{array}$ & $\begin{array}{l}-0.117 * * * \\
(-2.747)\end{array}$ & $\begin{array}{c}0.010 \\
(0.255) \\
\end{array}$ & $\begin{array}{l}0.507 * * * \\
(12.707) \\
\end{array}$ & $\begin{array}{c}0.048 \\
(1.163) \\
\end{array}$ & $34.892 * * *$ & 0.290 \\
\hline
\end{tabular}


APPENDIX 2: TABLE A.2 (Panel A) - Sample regression results: Low WAM sample $(n=247)$

\begin{tabular}{|c|c|c|c|c|c|c|c|c|c|}
\hline \multirow[t]{2}{*}{$\begin{array}{l}\text { Social networking } \\
\text { time }\end{array}$} & \multirow[b]{2}{*}{ Dependent variable } & $\begin{array}{c}\text { Social } \\
\text { networking } \\
\text { time }\end{array}$ & $\begin{array}{l}\text { Accounting } \\
\text { major } \\
\text { dummy } \\
\end{array}$ & Age & $\begin{array}{l}\text { Gender } \\
\text { dummy }\end{array}$ & WAM & $\begin{array}{l}\text { Year of } \\
\text { study }\end{array}$ & \multirow[b]{2}{*}{ F-stat } & \multirow[b]{2}{*}{ Adj. R square } \\
\hline & & \multicolumn{6}{|c|}{ Coefficient $(t-$ stat $)$} & & \\
\hline \multirow{5}{*}{ Facebook } & Decision making (understand and apply) & $\begin{array}{l}-0.164 * * * \\
(-2.704)\end{array}$ & $\begin{array}{c}0.032 \\
(0.530)\end{array}$ & $\begin{array}{c}-0.057 \\
(-0.857)\end{array}$ & $\begin{array}{c}0.085 \\
(1.414)\end{array}$ & $\begin{array}{l}0.268 * * * \\
(4.277)\end{array}$ & $\begin{array}{l}0.107 * \\
(1.693)\end{array}$ & $5.090 * * *$ & 0.087 \\
\hline & Cost volume profit (understand and apply) & $\begin{array}{l}-0.183 * * * \\
(-3.007)\end{array}$ & $\begin{array}{l}-0.001 \\
(-0.024)\end{array}$ & $\begin{array}{c}0.013 \\
(0.199)\end{array}$ & $\begin{array}{c}0.113^{*} \\
(1.873)\end{array}$ & $\begin{array}{l}0.260 * * * \\
(4.148)\end{array}$ & $\begin{array}{c}0.072 \\
(1.142)\end{array}$ & $4.990 * * *$ & 0.085 \\
\hline & Financial accounting (understand, apply and analyse) & $\begin{array}{l}-0.145 * * \\
(-2.465)\end{array}$ & $\begin{array}{l}-0.022 \\
(-0.384)\end{array}$ & $\begin{array}{l}-0.063 \\
(-0.986)\end{array}$ & $\begin{array}{c}0.024 \\
(0.407)\end{array}$ & $\begin{array}{l}0.376^{* * * *} \\
(6.190)\end{array}$ & $\begin{array}{c}0.033 \\
(0.538)\end{array}$ & $8.262^{* * *}$ & 0.144 \\
\hline & Activity based costing (apply and analyse) & $\begin{array}{l}-0.035 \\
(-0.554)\end{array}$ & $\begin{array}{c}0.074 \\
(1.183)\end{array}$ & $\begin{array}{c}0.008 \\
(0.122)\end{array}$ & $\begin{array}{c}0.009 \\
(0.152)\end{array}$ & $\begin{array}{l}0.181 * * * \\
(2.785)\end{array}$ & $\begin{array}{c}0.077 \\
(1.166)\end{array}$ & $1.713^{* * *}$ & 0.016 \\
\hline & Earnings management (evaluate) & $\begin{array}{c}0.020 \\
(0.353)\end{array}$ & $\begin{array}{l}-0.015 \\
(-0.263)\end{array}$ & $\begin{array}{l}-0.195^{* * * *} \\
(-3.200)\end{array}$ & $\begin{array}{c}0.064 \\
(1.153)\end{array}$ & $\begin{array}{l}0.393 * * * \\
(6.798)\end{array}$ & $\begin{array}{c}0.072 \\
(1.226)\end{array}$ & $13.264 * * *$ & 0.222 \\
\hline \multirow{5}{*}{$\begin{array}{l}\text { Education and } \\
\text { study*FB time }\end{array}$} & Decision making (understand and apply) & $\begin{array}{l}-0.169 * * * \\
(-2.725)\end{array}$ & $\begin{array}{c}0.032 \\
(0.524)\end{array}$ & $\begin{array}{l}-0.053 \\
(-0.785)\end{array}$ & $\begin{array}{c}0.069 \\
(1.116)\end{array}$ & $\begin{array}{l}0.266^{* * *} \\
(4.147)\end{array}$ & $\begin{array}{c}0.113^{*} \\
(1.744)\end{array}$ & $4.735^{* * *}$ & 0.083 \\
\hline & Cost volume profit (understand and apply) & $\begin{array}{l}-0.188 * * * \\
(-3.018)\end{array}$ & $\begin{array}{l}-0.003 \\
(-0.051)\end{array}$ & $\begin{array}{c}0.002 \\
(0.032)\end{array}$ & $\begin{array}{c}0.105^{*} \\
(1.710)\end{array}$ & $\begin{array}{l}0.254 * * * \\
(3.961)\end{array}$ & $\begin{array}{c}0.082 \\
(1.260)\end{array}$ & $4.654 * * *$ & 0.082 \\
\hline & Financial accounting (understand, apply and analyse) & $\begin{array}{l}-0.129 * * \\
(-2.150)\end{array}$ & $\begin{array}{l}-0.022 \\
(-0.370)\end{array}$ & $\begin{array}{l}-0.058 \\
(-0.886)\end{array}$ & $\begin{array}{c}0.005 \\
(0.085)\end{array}$ & $\begin{array}{l}0.379 * * * \\
(6.102)\end{array}$ & $\begin{array}{c}0.047 \\
(0.749)\end{array}$ & $7.688^{* * *}$ & 0.140 \\
\hline & Activity based costing (apply and analyse) & $\begin{array}{l}-0.035 \\
(-0.547)\end{array}$ & $\begin{array}{c}0.074 \\
(1.151)\end{array}$ & $\begin{array}{c}0.011 \\
(0.157)\end{array}$ & $\begin{array}{c}0.015 \\
(0.236)\end{array}$ & $\begin{array}{l}0.174 * * * \\
(2.618)\end{array}$ & $\begin{array}{c}0.070 \\
(1.048)\end{array}$ & 1.525 & 0.013 \\
\hline & Earnings management (evaluate) & $\begin{array}{c}0.011 \\
(0.187) \\
\end{array}$ & $\begin{array}{c}-0.010 \\
(-0.168)\end{array}$ & $\begin{array}{l}-0.190 * * * \\
(-3.022)\end{array}$ & $\begin{array}{c}0.044 \\
(0.762) \\
\end{array}$ & $\begin{array}{l}0.388^{* * * *} \\
(6.508)\end{array}$ & $\begin{array}{c}0.075 \\
(1.241)\end{array}$ & $11.757 * * *$ & 0.207 \\
\hline \multirow{5}{*}{$\begin{array}{l}\text { Ask a classmate } \\
\text { for help in the } \\
\text { class*FB time }\end{array}$} & Decision making (understand and apply) & $\begin{array}{l}-0.181 * * * \\
(-2.885)\end{array}$ & $\begin{array}{c}0.027 \\
(0.432)\end{array}$ & $\begin{array}{l}-0.064 \\
(-0.941)\end{array}$ & $\begin{array}{c}0.072 \\
(1.170)\end{array}$ & $\begin{array}{l}0.264 * * * \\
(4.131)\end{array}$ & $\begin{array}{c}0.119^{*} \\
(1.839)\end{array}$ & $4.897 * * *$ & 0.086 \\
\hline & Cost volume profit (understand and apply) & $\begin{array}{l}-0.203 * * * \\
(-3.226)\end{array}$ & $\begin{array}{l}-0.010 \\
(-0.156)\end{array}$ & $\begin{array}{l}-0.010 \\
(-0.150)\end{array}$ & $\begin{array}{c}0.109^{*} \\
(1.773)\end{array}$ & $\begin{array}{l}0.252 * * * \\
(3.946)\end{array}$ & $\begin{array}{c}0.089 \\
(1.370)\end{array}$ & $4.887^{* * *}$ & 0.086 \\
\hline & Financial accounting (understand, apply and analyse) & $\begin{array}{l}-0.175 * * * \\
(-2.888)\end{array}$ & $\begin{array}{l}-0.030 \\
(-0.504)\end{array}$ & $\begin{array}{l}-0.073 \\
(-1.115)\end{array}$ & $\begin{array}{c}0.009 \\
(0.145)\end{array}$ & $\begin{array}{l}0.380 * * * \\
(6.173)\end{array}$ & $\begin{array}{c}0.056 \\
(0.903)\end{array}$ & $8.413 * * *$ & 0.153 \\
\hline & Activity based costing (apply and analyse) & $\begin{array}{l}-0.082 \\
(-1.260)\end{array}$ & $\begin{array}{c}0.068 \\
(1.065)\end{array}$ & $\begin{array}{c}0.001 \\
(0.008)\end{array}$ & $\begin{array}{c}0.017 \\
(0.267)\end{array}$ & $\begin{array}{l}0.177 * * * \\
(2.669)\end{array}$ & $\begin{array}{c}0.077 \\
(1.150)\end{array}$ & 1.747 & 0.018 \\
\hline & Earnings management (evaluate) & $\begin{array}{c}0.045 \\
(0.774)\end{array}$ & $\begin{array}{l}-0.006 \\
(-0.105)\end{array}$ & $\begin{array}{l}-0.183 * * * \\
(-2.895)\end{array}$ & $\begin{array}{c}0.042 \\
(0.742)\end{array}$ & $\begin{array}{l}0.386 * * * \\
(6.485)\end{array}$ & $\begin{array}{c}0.070 \\
(1.162)\end{array}$ & $11.849 * * *$ & 0.209 \\
\hline
\end{tabular}


APPENDIX 2: TABLE A.2 (Panel B) - Sample regression results: High WAM sample $(n=246)$

\begin{tabular}{|c|c|c|c|c|c|c|c|c|c|}
\hline \multirow[t]{2}{*}{$\begin{array}{l}\text { Social } \\
\text { networking } \\
\text { time }\end{array}$} & \multirow[b]{2}{*}{ Dependent variable } & $\begin{array}{c}\text { Social } \\
\text { networking } \\
\text { time } \\
\end{array}$ & $\begin{array}{l}\text { Accounting } \\
\text { major } \\
\text { dummy } \\
\end{array}$ & Age & $\begin{array}{l}\text { Gender } \\
\text { dummy }\end{array}$ & WAM & $\begin{array}{c}\text { Year of } \\
\text { study }\end{array}$ & \multirow[b]{2}{*}{ F-stat } & \multirow[b]{2}{*}{ Adj. R square } \\
\hline & & \multicolumn{6}{|c|}{ Coefficient $(t-$ stat $)$} & & \\
\hline \multirow{5}{*}{ Facebook } & Decision making (understand and apply) & $\begin{array}{c}-0.027 \\
(-0.442)\end{array}$ & $\begin{array}{c}0.079 \\
(1.314)\end{array}$ & $\begin{array}{l}0.163 * * \\
(2.518)\end{array}$ & $\begin{array}{c}0.081 \\
(1.326)\end{array}$ & $\begin{array}{l}0.252^{* * * *} \\
(4.182)\end{array}$ & $\begin{array}{c}-0.061 \\
(-0.944)\end{array}$ & $4.840 * * *$ & 0.082 \\
\hline & Cost volume profit (understand and apply) & $\begin{array}{c}0.004 \\
(0.061)\end{array}$ & $\begin{array}{c}0.115^{*} \\
(1.887)\end{array}$ & $\begin{array}{c}-0.024 \\
(-0.367)\end{array}$ & $\begin{array}{c}0.103^{*} \\
(1.684)\end{array}$ & $\begin{array}{l}0.256^{* * * *} \\
(4.221)\end{array}$ & $\begin{array}{c}0.000 \\
(0.000)\end{array}$ & $4.107 * * *$ & 0.067 \\
\hline & Financial accounting (understand, apply and analyse) & $\begin{array}{c}0.014 \\
(0.229)\end{array}$ & $\begin{array}{c}0.096 \\
(1.594)\end{array}$ & $\begin{array}{c}-0.044 \\
(-0.675)\end{array}$ & $\begin{array}{c}0.005 \\
(0.076)\end{array}$ & $\begin{array}{l}0.308^{* * * *} \\
(5.113)\end{array}$ & $\begin{array}{c}0.055 \\
(0.847)\end{array}$ & $4.890 * * *$ & 0.083 \\
\hline & Activity based costing (apply and analyse) & $\begin{array}{c}-0.048 \\
(-0.777)\end{array}$ & $\begin{array}{c}0.051 \\
(0.828)\end{array}$ & $\begin{array}{c}0.086 \\
(1.311)\end{array}$ & $\begin{array}{l}0.128 * * \\
(2.072)\end{array}$ & $\begin{array}{l}0.219 * * * \\
(3.579)\end{array}$ & $\begin{array}{c}-0.018 \\
(-0.268)\end{array}$ & $3.521 * * *$ & 0.055 \\
\hline & Earnings management (evaluate) & $\begin{array}{c}0.033 \\
(0.541)\end{array}$ & $\begin{array}{c}0.105^{*} \\
(1.701)\end{array}$ & $\begin{array}{c}-0.056 \\
(-0.849)\end{array}$ & $\begin{array}{c}-0.025 \\
(-0.400)\end{array}$ & $\begin{array}{l}0.243 * * * \\
(3.977)\end{array}$ & $\begin{array}{c}0.029 \\
(0.442)\end{array}$ & $3.347 * * *$ & 0.052 \\
\hline \multirow{4}{*}{$\begin{array}{l}\text { Education and } \\
\text { study*FB } \\
\text { time }\end{array}$} & Decision making (understand and apply) & $\begin{array}{c}0.013 \\
(0.213)\end{array}$ & $\begin{array}{c}0.075 \\
(1.216)\end{array}$ & $\begin{array}{l}0.171 * * \\
(2.550)\end{array}$ & $\begin{array}{c}0.098 \\
(1.582)\end{array}$ & $\begin{array}{l}0.258^{* * *} \\
(4.197)\end{array}$ & $\begin{array}{l}-0.070 \\
(-1.051)\end{array}$ & $4.871^{* * *}$ & 0.086 \\
\hline & Cost volume profit (understand and apply) & $\begin{array}{c}-0.008 \\
(-0.127)\end{array}$ & $\begin{array}{c}0.102 \\
(1.640)\end{array}$ & $\begin{array}{c}0.020 \\
(0.298)\end{array}$ & $\begin{array}{c}0.093 \\
(1.477)\end{array}$ & $\begin{array}{l}0.258 * * * \\
(4.138)\end{array}$ & $\begin{array}{l}-0.021 \\
(-0.310)\end{array}$ & $3.838^{* * * *}$ & 0.065 \\
\hline & Activity based costing (apply and analyse) & $\begin{array}{c}-0.052 \\
(-0.832)\end{array}$ & $\begin{array}{c}0.029 \\
(0.462)\end{array}$ & $\begin{array}{c}0.119 * \\
(1.756)\end{array}$ & $\begin{array}{l}0.126^{* *} \\
(2.011)\end{array}$ & $\begin{array}{l}0.225^{* * *} \\
(3.615)\end{array}$ & $\begin{array}{l}-0.040 \\
(-0.590)\end{array}$ & $3.726^{* * *}$ & 0.062 \\
\hline & Earnings management (evaluate) & $\begin{array}{c}0.026 \\
(0.413)\end{array}$ & $\begin{array}{c}0.088 \\
(1.386)\end{array}$ & $\begin{array}{c}-0.041 \\
(-0.599)\end{array}$ & $\begin{array}{c}-0.019 \\
(-0.292)\end{array}$ & $\begin{array}{l}0.227 * * * \\
(3.592)\end{array}$ & $\begin{array}{c}0.017 \\
(0.247) \\
\end{array}$ & $2.648^{* *}$ & 0.039 \\
\hline \multirow{5}{*}{$\begin{array}{l}\text { Ask a } \\
\text { classmate for } \\
\text { help in the } \\
\text { class*FB time }\end{array}$} & Decision making (understand and apply) & $\begin{array}{c}-0.030 \\
(-0.486)\end{array}$ & $\begin{array}{c}0.072 \\
(1.169)\end{array}$ & $\begin{array}{l}0.164 * * \\
(2.450)\end{array}$ & $\begin{array}{c}0.096 \\
(1.547)\end{array}$ & $\begin{array}{l}0.257 * * * \\
(4.175)\end{array}$ & $\begin{array}{c}-0.069 \\
(-1.039)\end{array}$ & $4.907 * * *$ & 0.087 \\
\hline & Cost volume profit (understand and apply) & $\begin{array}{c}-0.019 \\
(-0.302)\end{array}$ & $\begin{array}{c}0.101 \\
(1.625)\end{array}$ & $\begin{array}{c}0.018 \\
(0.271)\end{array}$ & $\begin{array}{c}0.092 \\
(1.469)\end{array}$ & $\begin{array}{l}0.257^{* * * *} \\
(4.126)\end{array}$ & $\begin{array}{l}-0.020 \\
(-0.305)\end{array}$ & $3.852 * * *$ & 0.065 \\
\hline & Financial accounting (understand, apply and analyse) & $\begin{array}{l}-0.036 \\
(-0.571)\end{array}$ & $\begin{array}{c}0.076 \\
(1.222)\end{array}$ & $\begin{array}{c}-0.025 \\
(-0.365)\end{array}$ & $\begin{array}{c}0.008 \\
(0.125)\end{array}$ & $\begin{array}{l}0.302 * * * \\
(4.880)\end{array}$ & $\begin{array}{c}0.044 \\
(0.657)\end{array}$ & $4.400 * * *$ & 0.077 \\
\hline & Activity based costing (apply and analyse) & $\begin{array}{c}-0.068 \\
(-1.084)\end{array}$ & $\begin{array}{c}0.027 \\
(0.433)\end{array}$ & $\begin{array}{r}0.116^{*} \\
(1.710)\end{array}$ & $\begin{array}{l}0.126^{* *} \\
(2.002)\end{array}$ & $\begin{array}{l}0.223 * * * \\
(3.584)\end{array}$ & $\begin{array}{l}-0.039 \\
(-0.576)\end{array}$ & $3.813^{* * *}$ & 0.064 \\
\hline & Earnings management (evaluate) & $\begin{array}{c}0.019 \\
(0.295)\end{array}$ & $\begin{array}{c}0.088 \\
(1.382)\end{array}$ & $\begin{array}{c}-0.042 \\
(-0.610)\end{array}$ & $\begin{array}{c}-0.019 \\
(-0.299)\end{array}$ & $\begin{array}{l}0.227 * * * \\
(3.595)\end{array}$ & $\begin{array}{c}0.017 \\
(0.245)\end{array}$ & $2.634 * *$ & 0.038 \\
\hline
\end{tabular}




\section{Tables}

\section{TABLE 1}

Descriptive statistics and frequencies for complete sample $(\boldsymbol{n}=\mathbf{5 0 5})$

\begin{tabular}{|c|c|c|c|c|c|c|}
\hline \multicolumn{7}{|l|}{ Panel A: Descriptive statistics - continuous variables } \\
\hline & Min. & Max. & Mean & Median & Std. Dev. & $\begin{array}{l}\text { Mean \% } \\
\text { mark }\end{array}$ \\
\hline Decision marking (understand and apply) & 0.000 & 10.000 & 4.495 & 4.000 & 3.428 & 44.950 \\
\hline Cost volume profit analysis (understand and apply) & 0.000 & 10.000 & 5.246 & 6.000 & 3.248 & 52.460 \\
\hline Financial accounting (understand, apply and analyse) & 0.000 & 24.000 & 14.183 & 15.000 & 5.436 & 59.096 \\
\hline Activity based costing (apply and analyse) & 0.000 & 13.000 & 5.704 & 6.000 & 4.767 & 43.877 \\
\hline Earnings management (evaluate) & 0.000 & 22.000 & 10.895 & 11.000 & 6.050 & 49.523 \\
\hline Facebook time (minutes per day) & 0.000 & 1440.000 & 116.641 & 90.000 & 125.141 & \\
\hline Age & 17.067 & 51.770 & 19.601 & 18.508 & 3.245 & \\
\hline WAM & 31.000 & 91.330 & 71.785 & 73.000 & 9.977 & \\
\hline Year of study & 0.000 & 4.500 & 0.185 & 0.000 & 0.569 & \\
\hline \multirow[t]{2}{*}{ Panel B: Frequencies - dummy variables } & \multicolumn{4}{|c|}{ Binary codes } & & \\
\hline & \multicolumn{2}{|r|}{$\mathbf{0}$} & \multicolumn{2}{|c|}{1} & & \\
\hline \multirow{2}{*}{$\begin{array}{l}\text { Accounting Major } \\
\text { Gender }\end{array}$} & \multicolumn{2}{|r|}{447} & \multicolumn{2}{|c|}{58} & & \\
\hline & \multicolumn{2}{|r|}{284} & \multicolumn{2}{|c|}{221} & & \\
\hline
\end{tabular}


TABLE 2

Facebook use $(n=505)$

\section{Panel A: General reasons for using Facebook}

\begin{tabular}{|c|c|c|c|c|c|c|c|}
\hline General reasons for using Facebook & $\begin{array}{c}\text { Strongly } \\
\text { disagree } \\
\text { (1) }\end{array}$ & $\begin{array}{c}\text { Disagree } \\
\text { (2) }\end{array}$ & $\begin{array}{l}\text { Neither } \\
\text { agree nor } \\
\text { disagree } \\
\text { (3) }\end{array}$ & Agree (4) & $\begin{array}{l}\text { Strongly } \\
\text { agree (5) }\end{array}$ & $\begin{array}{c}\text { Mean } \\
(1-5)\end{array}$ & Ranking \\
\hline Communications with friends and family & 0.4 & 1.6 & 6.6 & 36.3 & 55.1 & 4.441 & 1 \\
\hline Enjoyment and entertainment & 2.7 & 3.5 & 14.5 & 46.3 & 33.0 & 4.033 & 2 \\
\hline Filling in 'dead' or vacant time & 4.3 & 5.5 & 18.0 & 37.7 & 34.6 & 3.928 & 3 \\
\hline Keeping informed about events and news & 3.5 & 5.1 & 16.0 & 48.0 & 27.3 & 3.906 & 4 \\
\hline Education and study & 3.5 & 11.7 & 27.5 & 44.1 & 13.1 & 3.516 & 5 \\
\hline Work related reasons & 9.6 & 21.7 & 35.2 & 25.2 & 8.4 & 3.012 & 6 \\
\hline
\end{tabular}

\section{Panel B: Specific university study reasons for using Facebook}

\begin{tabular}{|c|c|c|c|c|c|c|c|}
\hline & $\begin{array}{c}\text { Very } \\
\text { unlikely } \\
(1)\end{array}$ & $\begin{array}{c}\text { Unlikely } \\
\text { (2) }\end{array}$ & $\begin{array}{l}\text { Neither } \\
\text { unlikely or } \\
\text { likely (3) }\end{array}$ & Likely (4) & $\begin{array}{l}\text { Very } \\
\text { likely } \\
(5)\end{array}$ & $\begin{array}{l}\text { Mean } \\
(1-5)\end{array}$ & Ranking \\
\hline Arrange a meeting for a group project & 2.3 & 4.5 & 6.8 & 38.2 & 48.1 & 4.252 & 1 \\
\hline Contact another student with a question related to class or university work & 2.7 & 4.7 & 9.2 & 42.2 & 41.2 & 4.145 & 2 \\
\hline Discuss university work & 2.5 & 6.3 & 14.5 & 40.3 & 36.4 & 4.018 & 3 \\
\hline Ask a classmate for help in the class & 3.7 & 7.0 & 13.7 & 39.6 & 35.9 & 3.971 & 4 \\
\hline Help manage a group project & 1.4 & 4.1 & 8.6 & 70.6 & 15.3 & 3.943 & 5 \\
\hline Collaborate on an assignment in a way my instructor would like & 3.1 & 7.0 & 18.6 & 38.4 & 32.9 & 3.908 & 6 \\
\hline Arrange a face-to-face study group & 4.5 & 10.5 & 15.6 & 36.7 & 32.6 & 3.824 & 7 \\
\hline
\end{tabular}


TABLE 3

Descriptive statistics for time on Facebook per day multiplied by extent/likelihood of use $(n=505)$

\section{Panel A: General reasons for using Facebook}

\begin{tabular}{|c|c|c|c|c|c|}
\hline & Min. & Max. & Mean & Median & Std. Dev. \\
\hline Communications with friends and family*time on Facebook & 0.000 & 2150.000 & 493.592 & 450.000 & 415.928 \\
\hline Enjoyment and entertainment*time on Facebook & 0.000 & 2150.000 & 458.612 & 360.000 & 400.810 \\
\hline Filling in 'dead' or vacant time*time on Facebook & 0.000 & 2400.000 & 452.448 & 360.000 & 406.047 \\
\hline Keeping informed about events and news*time on Facebook & 0.000 & 2150.000 & 447.345 & 360.000 & 399.544 \\
\hline Education and study*time on Facebook & 0.000 & 2150.000 & 389.560 & 300.000 & 356.974 \\
\hline Work related reasons*time on Facebook & 0.000 & 1950.000 & 341.160 & 240.000 & 329.742 \\
\hline
\end{tabular}

\section{Panel B: Specific university study reasons for using Facebook}

\begin{tabular}{|c|c|c|c|c|c|}
\hline & Min. & Max. & Mean & Median & Std. Dev. \\
\hline Arrange a meeting for a group project*time on Facebook & 0.000 & 2550.000 & 472.040 & 360.000 & 410.917 \\
\hline $\begin{array}{l}\text { Contact another student with a question related to class or university } \\
\text { work*time on Facebook }\end{array}$ & 0.000 & 2550.000 & 466.384 & 360.000 & 413.129 \\
\hline Discuss university work*time on Facebook & 0.000 & 2550.000 & 455.760 & 360.000 & 415.587 \\
\hline Ask a classmate for help in the class*time on Facebook & 0.000 & 2550.000 & 449.919 & 300.000 & 416.112 \\
\hline Help manage a group project*time on Facebook & 0.000 & 2550.000 & 436.248 & 360.000 & 381.138 \\
\hline $\begin{array}{l}\text { Collaborate on an assignment in a way my instructor would like*time } \\
\text { on Facebook }\end{array}$ & 0.000 & 2150.000 & 438.299 & 320.000 & 392.941 \\
\hline
\end{tabular}


TABLE 4 - Regression results: Full sample $(\boldsymbol{n}=\mathbf{5 0 5})$

\begin{tabular}{|c|c|c|c|c|c|c|c|}
\hline Social networking time & Facebook time & $\begin{array}{l}\text { Communications } \\
\text { with friends and } \\
\text { family*FB time }\end{array}$ & $\begin{array}{l}\text { Enjoyment and } \\
\text { entertainment*FB time }\end{array}$ & $\begin{array}{l}\text { Filling in 'dead' or } \\
\text { vacant time*FB time }\end{array}$ & $\begin{array}{l}\text { Keeping informed } \\
\text { about events and } \\
\text { news*FB time }\end{array}$ & $\begin{array}{l}\text { Education and } \\
\text { study*FB time }\end{array}$ & $\begin{array}{l}\text { Work related } \\
\text { reasons*FB time }\end{array}$ \\
\hline Dependent variables & & & & Coefficient $(t$-stat $)$ & & & \\
\hline Decision making (understand and apply) & $\begin{array}{l}-0.082^{* *} \\
(-2.045)\end{array}$ & $\begin{array}{c}-0.078^{*} \\
(1.898)\end{array}$ & $\begin{array}{l}-0.069^{*} \\
(-1.703)\end{array}$ & $\begin{array}{l}-0.077 * * \\
(-1.887)\end{array}$ & $\begin{array}{l}-0.064 \\
(-1.566)\end{array}$ & $\begin{array}{l}-0.067 * \\
(-1.656)\end{array}$ & $\begin{array}{l}-0.078^{*} \\
(-1.915)\end{array}$ \\
\hline Cost volume profit (understand and apply) & $\begin{array}{l}-0.085 * * \\
(-2.200)\end{array}$ & $\begin{array}{l}-0.089 * * \\
(-2.241)\end{array}$ & $\begin{array}{l}-0.087^{* *} \\
(-2.206)\end{array}$ & $\begin{array}{l}-0.094 * * \\
(-2.388)\end{array}$ & $\begin{array}{l}-0.083^{* *} \\
(-2.096)\end{array}$ & $\begin{array}{l}-0.090 * * \\
(-2.293)\end{array}$ & $\begin{array}{l}-0.104 * * * \\
(-2.637)\end{array}$ \\
\hline $\begin{array}{l}\text { Financial accounting (understand, apply and } \\
\text { analyse) }\end{array}$ & $\begin{array}{l}-0.060 \\
(-1.626)\end{array}$ & $\begin{array}{l}-0.062 \\
(-1.633)\end{array}$ & $\begin{array}{l}-0.059 \\
(-1.577)\end{array}$ & $\begin{array}{l}-0.068^{*} \\
(-1.804)\end{array}$ & $\begin{array}{l}-0.065^{*} \\
(-1.716)\end{array}$ & $\begin{array}{l}-0.072 * \\
(-1.929)\end{array}$ & $\begin{array}{l}-0.082^{* *} \\
(-2.182)\end{array}$ \\
\hline Activity based costing (apply and analyse) & $\begin{array}{l}-0.040 \\
(-0.963)\end{array}$ & $\begin{array}{l}-0.065 \\
(-1.523)\end{array}$ & $\begin{array}{l}-0.066 \\
(-1.570)\end{array}$ & $\begin{array}{l}-0.065 \\
(1.531)\end{array}$ & $\begin{array}{c}-0.049 \\
(-1.157)\end{array}$ & $\begin{array}{l}-0.048 \\
(-1.137)\end{array}$ & $\begin{array}{c}-0.043 \\
(-1.014)\end{array}$ \\
\hline Earnings management (evaluate) & $\begin{array}{c}0.027 \\
(0.719)\end{array}$ & $\begin{array}{c}0.039 \\
(1.006)\end{array}$ & $\begin{array}{c}0.027 \\
(0.709)\end{array}$ & $\begin{array}{c}0.036 \\
(0.954)\end{array}$ & $\begin{array}{c}0.022 \\
(0.561)\end{array}$ & $\begin{array}{c}0.020 \\
(0.511)\end{array}$ & $\begin{array}{c}0.002 \\
(0.039)\end{array}$ \\
\hline Social networking time & $\begin{array}{l}\text { Arrange a meeting for a } \\
\text { group project*FB time }\end{array}$ & $\begin{array}{l}\text { Contact another } \\
\text { student with a } \\
\text { question related to } \\
\text { class or university } \\
\text { work*FB time }\end{array}$ & $\begin{array}{l}\text { Discuss university } \\
\text { work*FB time }\end{array}$ & $\begin{array}{l}\text { Ask a classmate for } \\
\text { help in the class*FB } \\
\text { time }\end{array}$ & $\begin{array}{l}\text { Help manage a } \\
\text { group project*FB } \\
\text { time }\end{array}$ & $\begin{array}{l}\text { Collaborate on an } \\
\text { assignment in a way } \\
\text { my instructor would } \\
\text { like*FB time }\end{array}$ & $\begin{array}{l}\text { Arrange a face-to- } \\
\text { face study group*FB } \\
\text { time }\end{array}$ \\
\hline Decision making (understand and apply) & $\begin{array}{l}-0.084 * * \\
(-2.064)\end{array}$ & $\begin{array}{l}-0.075^{*} \\
(-1.831)\end{array}$ & $\begin{array}{l}-0.080^{*} \\
(-1.953)\end{array}$ & $\begin{array}{l}-0.090^{* *} \\
(-2.189)\end{array}$ & $\begin{array}{l}-0.062 \\
(-1.510)\end{array}$ & $\begin{array}{l}-0.085^{* *} \\
(-2.091)\end{array}$ & $\begin{array}{l}-0.086^{* *} \\
(-2.105)\end{array}$ \\
\hline Cost volume profit (understand and apply) & $\begin{array}{l}-0.088 * * \\
(-2.230)\end{array}$ & $\begin{array}{l}-0.085^{* *} \\
(-2.152)\end{array}$ & $\begin{array}{l}-0.095^{* *} \\
(-2.410)\end{array}$ & $\begin{array}{l}-0.101 * * \\
(-2.542)\end{array}$ & $\begin{array}{l}-0.060 \\
(-1.522)\end{array}$ & $\begin{array}{l}-0.096^{* *} \\
(-2.427)\end{array}$ & $\begin{array}{l}-0.101 * * * \\
(-2.577)\end{array}$ \\
\hline $\begin{array}{l}\text { Financial accounting (understand, apply and } \\
\text { analyse) }\end{array}$ & $\begin{array}{l}-0.078 * * \\
(-2.075)\end{array}$ & $\begin{array}{l}-0.075^{* *} \\
(-1.999)\end{array}$ & $\begin{array}{l}-0.070^{*} \\
(-1.865)\end{array}$ & $\begin{array}{l}-0.091 * * \\
(-2.422)\end{array}$ & $\begin{array}{l}-0.068^{*} \\
(-1.812)\end{array}$ & $\begin{array}{l}-0.071 * \\
(-1.899)\end{array}$ & $\begin{array}{l}-0.069 * \\
(-1.846)\end{array}$ \\
\hline Activity based costing (apply and analyse) & $\begin{array}{l}-0.083 * * \\
(-1.967)\end{array}$ & $\begin{array}{l}-0.063 \\
(-1.481)\end{array}$ & $\begin{array}{l}-0.081^{*} \\
(-1.918)\end{array}$ & $\begin{array}{l}-0.074^{*} \\
(-1.740)\end{array}$ & $\begin{array}{l}-0.057 \\
(-1.345)\end{array}$ & $\begin{array}{l}-0.069 \\
(-1.627)\end{array}$ & $\begin{array}{l}-0.074^{*} \\
(-1.748)\end{array}$ \\
\hline Earnings management (evaluate) & $\begin{array}{c}0.043 \\
(1.130)\end{array}$ & $\begin{array}{c}0.040 \\
(1.031)\end{array}$ & $\begin{array}{c}0.035 \\
(0.913)\end{array}$ & $\begin{array}{c}0.034 \\
(0.885)\end{array}$ & $\begin{array}{c}0.047 \\
(1.241)\end{array}$ & $\begin{array}{c}0.030 \\
(0.770)\end{array}$ & $\begin{array}{c}0.019 \\
(0.503)\end{array}$ \\
\hline
\end{tabular}


TABLE 5 (Panel A) - Regression results: Low WAM sample $(n=247)$

\begin{tabular}{|c|c|c|c|c|c|c|c|}
\hline Social networking time & Facebook time & $\begin{array}{l}\text { Communications } \\
\text { with friends and } \\
\text { family*FB time }\end{array}$ & $\begin{array}{l}\text { Enjoyment and } \\
\text { entertainment*FB time }\end{array}$ & $\begin{array}{l}\text { Filling in 'dead' or } \\
\text { vacant time*FB time }\end{array}$ & $\begin{array}{l}\text { Keeping informed } \\
\text { about events and } \\
\text { news*FB time }\end{array}$ & $\begin{array}{l}\text { Education and } \\
\text { study*FB time }\end{array}$ & $\begin{array}{l}\text { Work related } \\
\text { reasons*FB time }\end{array}$ \\
\hline Dependent variables & & & & Coefficient $(t$-stat $)$ & & & \\
\hline Decision making (understand and apply) & $\begin{array}{l}-0.164 * * * \\
(-2.704)\end{array}$ & $\begin{array}{l}-0.157^{* *} \\
(-2.506)\end{array}$ & $\begin{array}{l}-0.136^{* *} \\
(-2.176)\end{array}$ & $\begin{array}{l}-0.159 * * \\
(-2.546)\end{array}$ & $\begin{array}{l}-0.127 * * \\
(-2.037)\end{array}$ & $\begin{array}{l}-0.169^{* * *} \\
(-2.725)\end{array}$ & $\begin{array}{l}-0.149 * * \\
(-2.387)\end{array}$ \\
\hline Cost volume profit (understand and apply) & $\begin{array}{l}-0.183 * * * \\
(-3.007)\end{array}$ & $\begin{array}{l}-0.175^{* * *} \\
(-2.799)\end{array}$ & $\begin{array}{l}-0.168 * * * \\
(-2.688)\end{array}$ & $\begin{array}{l}-0.182 * * * \\
(-2.921)\end{array}$ & $\begin{array}{l}-0.157 * * \\
(-2.514)\end{array}$ & $\begin{array}{l}-0.188^{* * *} \\
(-3.018)\end{array}$ & $\begin{array}{l}-0.172 * * * \\
(-2.758)\end{array}$ \\
\hline $\begin{array}{l}\text { Financial accounting (understand, apply and } \\
\text { analyse) }\end{array}$ & $\begin{array}{l}-0.145^{* *} \\
(-2.465)\end{array}$ & $\begin{array}{l}-0.132 * * \\
(-2.175)\end{array}$ & $\begin{array}{l}-0.132 * * \\
(-2.192)\end{array}$ & $\begin{array}{l}-0.156^{* * *} \\
(-2.593)\end{array}$ & $\begin{array}{l}-0.121 * * \\
(-2.004)\end{array}$ & $\begin{array}{l}-0.129 * * \\
(-2.150)\end{array}$ & $\begin{array}{l}-0.126 * * \\
(-2.093)\end{array}$ \\
\hline Activity based costing (apply and analyse) & $\begin{array}{l}-0.035 \\
(-0.554)\end{array}$ & $\begin{array}{l}-0.067 \\
(-1.037)\end{array}$ & $\begin{array}{l}-0.045 \\
(-0.691)\end{array}$ & $\begin{array}{l}-0.053 \\
(-0.823)\end{array}$ & $\begin{array}{l}-0.034 \\
(-0.529)\end{array}$ & $\begin{array}{l}-0.035 \\
(-0.547)\end{array}$ & $\begin{array}{l}-0.031 \\
(-0.474)\end{array}$ \\
\hline Earnings management (evaluate) & $\begin{array}{c}0.020 \\
(0.353)\end{array}$ & $\begin{array}{l}-0.057 \\
(0.989)\end{array}$ & $\begin{array}{c}0.430 \\
(0.741)\end{array}$ & $\begin{array}{c}0.059 \\
(1.026)\end{array}$ & $\begin{array}{c}0.058 \\
(0.998)\end{array}$ & $\begin{array}{c}0.011 \\
(0.187)\end{array}$ & $\begin{array}{c}0.026 \\
(0.458)\end{array}$ \\
\hline Social networking time & $\begin{array}{l}\text { Arrange a meeting for a } \\
\text { group project*FB time }\end{array}$ & $\begin{array}{l}\text { Contact another } \\
\text { student with a } \\
\text { question related to } \\
\text { class or university } \\
\text { work*FB time }\end{array}$ & $\begin{array}{l}\text { Discuss university } \\
\text { work*FB time }\end{array}$ & $\begin{array}{l}\text { Ask a classmate for } \\
\text { help in the class*FB } \\
\text { time }\end{array}$ & $\begin{array}{l}\text { Help manage a } \\
\text { group project*FB } \\
\text { time }\end{array}$ & $\begin{array}{l}\text { Collaborate on an } \\
\text { assignment in a way } \\
\text { my instructor would } \\
\text { like*FB time }\end{array}$ & $\begin{array}{l}\text { Arrange a face-to- } \\
\text { face study group*FB } \\
\text { time }\end{array}$ \\
\hline Decision making (understand and apply) & $\begin{array}{l}-0.169^{* * * *} \\
(-2.712)\end{array}$ & $\begin{array}{l}-0.155^{* *} \\
(-2.471)\end{array}$ & $\begin{array}{l}-0.160 * * \\
(-2.564)\end{array}$ & $\begin{array}{l}-0.181 * * * \\
(-2.885)\end{array}$ & $\begin{array}{l}-0.135^{* *} \\
(-2.159)\end{array}$ & $\begin{array}{l}-0.165^{* * *} \\
(-2.625)\end{array}$ & $\begin{array}{l}-0.176^{* * *} \\
(-2.832)\end{array}$ \\
\hline Cost volume profit (understand and apply) & $\begin{array}{l}-0.180 * * * \\
(-2.872)\end{array}$ & $\begin{array}{l}-0.172 * * * \\
(-2.726)\end{array}$ & $\begin{array}{l}-0.179 * * * \\
(-2.865)\end{array}$ & $\begin{array}{l}-0.203^{* * *} \\
(-3.226)\end{array}$ & $\begin{array}{l}-0.146 * * \\
(-2.316)\end{array}$ & $\begin{array}{l}-0.189 * * * \\
(-3.023)\end{array}$ & $\begin{array}{l}-0.192 * * * \\
(-3.085)\end{array}$ \\
\hline $\begin{array}{l}\text { Financial accounting (understand, apply and } \\
\text { analyse) }\end{array}$ & $\begin{array}{l}-0.151^{* *} \\
(-2.504)\end{array}$ & $\begin{array}{l}-0.151^{* *} \\
(-2.488)\end{array}$ & $\begin{array}{l}-0.151 * * \\
(-2.512)\end{array}$ & $\begin{array}{l}-0.175^{* * *} \\
(-2.888)\end{array}$ & $\begin{array}{l}-0.141 * * \\
(-2.342)\end{array}$ & $\begin{array}{l}-0.128 * * \\
(-2.113)\end{array}$ & $\begin{array}{l}-0.143^{* *} \\
(-2.384)\end{array}$ \\
\hline Activity based costing (apply and analyse) & $\begin{array}{l}-0.095 \\
(-1.475)\end{array}$ & $\begin{array}{l}-0.047 \\
(-0.730)\end{array}$ & $\begin{array}{l}-0.071 \\
(-1.091)\end{array}$ & $\begin{array}{l}-0.082 \\
(-1.260)\end{array}$ & $\begin{array}{l}-0.058 \\
(-0.900)\end{array}$ & $\begin{array}{l}-0.046 \\
(-0.708)\end{array}$ & $\begin{array}{l}-0.059 \\
(-0.919)\end{array}$ \\
\hline Earnings management (evaluate) & $\begin{array}{c}0.058 \\
(1.007)\end{array}$ & $\begin{array}{c}0.047 \\
(0.802)\end{array}$ & $\begin{array}{c}0.036 \\
(0.614)\end{array}$ & $\begin{array}{c}0.045 \\
(0.774)\end{array}$ & $\begin{array}{c}0.059 \\
(1.013)\end{array}$ & $\begin{array}{c}0.056 \\
(0.957)\end{array}$ & $\begin{array}{c}0.023 \\
(0.402)\end{array}$ \\
\hline
\end{tabular}


TABLE 5 (Panel B) - Regression results: High WAM sample $(n=246)$

\begin{tabular}{|c|c|c|c|c|c|c|c|}
\hline Social networking time & Facebook time & $\begin{array}{l}\text { Communications } \\
\text { with friends and } \\
\text { family*FB time }\end{array}$ & $\begin{array}{l}\text { Enjoyment and } \\
\text { entertainment*FB time }\end{array}$ & $\begin{array}{l}\text { Filling in 'dead' or } \\
\text { vacant time*FB time }\end{array}$ & $\begin{array}{l}\text { Keeping informed } \\
\text { about events and } \\
\text { news*FB time }\end{array}$ & $\begin{array}{l}\text { Education and } \\
\text { study*FB time }\end{array}$ & $\begin{array}{l}\text { Work related } \\
\text { reasons*FB time }\end{array}$ \\
\hline Dependent variables & & & & Coefficient $(t$-stat $)$ & & & \\
\hline Decision making (understand and apply) & $\begin{array}{l}-0.027 \\
(-0.442)\end{array}$ & $\begin{array}{l}-0.026 \\
(-0.424)\end{array}$ & $\begin{array}{l}-0.033 \\
(-0.531)\end{array}$ & $\begin{array}{l}-0.022 \\
(-0.356)\end{array}$ & $\begin{array}{l}-0.026 \\
(-0.422)\end{array}$ & $\begin{array}{c}0.013 \\
(0.213)\end{array}$ & $\begin{array}{l}-0.033 \\
(-0.530)\end{array}$ \\
\hline Cost volume profit (understand and apply) & $\begin{array}{c}0.004 \\
(0.061)\end{array}$ & $\begin{array}{l}-0.018 \\
(-0.294)\end{array}$ & $\begin{array}{l}-0.023 \\
(-0.366)\end{array}$ & $\begin{array}{l}-0.020 \\
(-0.319)\end{array}$ & $\begin{array}{l}-0.019 \\
(-0.310)\end{array}$ & $\begin{array}{l}-0.008 \\
(-0.127)\end{array}$ & $\begin{array}{l}-0.053 \\
(-0.853)\end{array}$ \\
\hline $\begin{array}{l}\text { Financial accounting (understand, apply and } \\
\text { analyse) }\end{array}$ & $\begin{array}{c}0.014 \\
(0.229)\end{array}$ & $\begin{array}{l}-0.008 \\
(-0.123)\end{array}$ & $\begin{array}{c}0.001 \\
(0.010)\end{array}$ & $\begin{array}{c}0.003 \\
(0.046)\end{array}$ & $\begin{array}{l}-0.021 \\
(-0.339)\end{array}$ & $\begin{array}{l}-0.030 \\
(-0.490)\end{array}$ & $\begin{array}{l}-0.054 \\
(-0.871)\end{array}$ \\
\hline Activity based costing (apply and analyse) & $\begin{array}{l}-0.048 \\
(-0.777)\end{array}$ & $\begin{array}{l}-0.063 \\
(-1.011)\end{array}$ & $\begin{array}{l}-0.094 \\
(-1.497)\end{array}$ & $\begin{array}{l}-0.078 \\
(-1.252)\end{array}$ & $\begin{array}{l}-0.063 \\
(-1.001)\end{array}$ & $\begin{array}{l}-0.052 \\
(-0.832)\end{array}$ & $\begin{array}{l}-0.052 \\
(-0.824)\end{array}$ \\
\hline Earnings management (evaluate) & $\begin{array}{c}0.033 \\
(0.541)\end{array}$ & $\begin{array}{c}0.014 \\
(0.226)\end{array}$ & $\begin{array}{c}0.007 \\
(0.114)\end{array}$ & $\begin{array}{c}0.010 \\
(0.159)\end{array}$ & $\begin{array}{l}-0.019 \\
(-0.297)\end{array}$ & $\begin{array}{c}0.026 \\
(0.413)\end{array}$ & $\begin{array}{l}-0.025 \\
(-0.401)\end{array}$ \\
\hline Social networking time & $\begin{array}{l}\text { Arrange a meeting for a } \\
\text { group project*FB time }\end{array}$ & $\begin{array}{l}\text { Contact another } \\
\text { student with a } \\
\text { question related to } \\
\text { class or university } \\
\text { work*FB time }\end{array}$ & $\begin{array}{l}\text { Discuss university } \\
\text { work*FB time }\end{array}$ & $\begin{array}{l}\text { Ask a classmate for } \\
\text { help in the class*FB } \\
\text { time }\end{array}$ & $\begin{array}{l}\text { Help manage a } \\
\text { group project*FB } \\
\text { time }\end{array}$ & $\begin{array}{l}\text { Collaborate on an } \\
\text { assignment in a way } \\
\text { my instructor would } \\
\text { like*FB time }\end{array}$ & $\begin{array}{c}\text { Arrange a face-to- } \\
\text { face study group*FB } \\
\text { time }\end{array}$ \\
\hline Decision making (understand and apply) & $\begin{array}{l}-0.029 \\
(-0.464)\end{array}$ & $\begin{array}{l}-0.023 \\
(-0.378)\end{array}$ & $\begin{array}{l}-0.017 \\
(-0.272)\end{array}$ & $\begin{array}{l}-0.030 \\
(-0.486)\end{array}$ & $\begin{array}{l}-0.017 \\
(-0.275)\end{array}$ & $\begin{array}{l}-0.040 \\
(-0.655)\end{array}$ & $\begin{array}{l}-0.017 \\
(-0.281)\end{array}$ \\
\hline Cost volume profit (understand and apply) & $\begin{array}{l}-0.011 \\
(-0.173)\end{array}$ & $\begin{array}{l}-0.012 \\
(-0.188)\end{array}$ & $\begin{array}{l}-0.018 \\
(-0.293)\end{array}$ & $\begin{array}{l}-0.019 \\
(-0.302)\end{array}$ & $\begin{array}{c}0.018 \\
(0.291)\end{array}$ & $\begin{array}{l}-0.240 \\
(-0.392)\end{array}$ & $\begin{array}{l}-0.023 \\
(-0.368)\end{array}$ \\
\hline $\begin{array}{l}\text { Financial accounting (understand, apply and } \\
\text { analyse) }\end{array}$ & $\begin{array}{l}-0.024 \\
(-0.391)\end{array}$ & $\begin{array}{l}-0.017 \\
(-0.271)\end{array}$ & $\begin{array}{c}0.001 \\
(0.020)\end{array}$ & $\begin{array}{l}-0.036 \\
(-0.571)\end{array}$ & $\begin{array}{l}-0.012 \\
(-0.188)\end{array}$ & $\begin{array}{l}-0.036 \\
(-0.582)\end{array}$ & $\begin{array}{l}-0.008 \\
(-0.129)\end{array}$ \\
\hline Activity based costing (apply and analyse) & $\begin{array}{l}-0.076 \\
(-1.209)\end{array}$ & $\begin{array}{l}-0.080 \\
(-1.275)\end{array}$ & $\begin{array}{l}-0.090 \\
(-1.443)\end{array}$ & $\begin{array}{l}-0.068 \\
(-1.084)\end{array}$ & $\begin{array}{l}-0.061 \\
(-0.983)\end{array}$ & $\begin{array}{l}-0.097 \\
(-1.564)\end{array}$ & $\begin{array}{l}-0.088 \\
(-1.406)\end{array}$ \\
\hline Earnings management (evaluate) & $\begin{array}{c}0.029 \\
(0.455)\end{array}$ & $\begin{array}{c}0.033 \\
(0.519)\end{array}$ & $\begin{array}{c}0.043 \\
(0.671)\end{array}$ & $\begin{array}{c}0.019 \\
(0.295)\end{array}$ & $\begin{array}{c}0.036 \\
(0.575)\end{array}$ & $\begin{array}{c}-0.001 \\
(-0.022)\end{array}$ & $\begin{array}{c}0.017 \\
(0.273)\end{array}$ \\
\hline
\end{tabular}

